\title{
Detection and analysis of morphotectonic features utilizing satellite remote sensing and GIS: An example in SW Jordan
}

\author{
Omar M.A. Radaideh ${ }^{\mathrm{a}, \mathrm{c}, *}$, Bernhard Grasemann $^{\mathrm{b}}$, Rostislav Melichar ${ }^{\mathrm{a}}$, Jon Mosar ${ }^{\mathrm{c}}$ \\ a Department of Geological Sciences, Masaryk University, Kotlářská 267/2, 61137 Brno, Czech Republic \\ b Department of Geodynamics and Sedimentology, University of Vienna, Althanstrasse 14, A-1090 Vienna, Austria \\ c Department of Geosciences and Earth Sciences, University of Fribourg, Chemin du Musée 6, 1700 Fribourg, Switzerland
}

\begin{abstract}
This study investigates the dominant orientations of morphological features and the relationship between these trends and the spatial orientation of tectonic structures in SW Jordan. Landsat 8 and hill-shaded images, constructed from $30 \mathrm{~m}$-resolution ASTER-GDEM data, were used for automatically extracting and mapping geological lineaments. The ASTER-GDEM was further utilized to automatically identify and extract drainage network. Morphological features were analyzed by means of azimuth frequency and length density distributions. Tectonic controls on the land surface were evaluated using longitudinal profiles of many westerly flowing streams. The profiles were taken directly across the northerly trending faults within a strong topographic transition between the low-gradient uplands and the deeply incised mountain front on the east side of the Dead Sea Fault Zone. Streams of the area are widely divergent, and show numerous anomalies along their profiles when they transect faults and lineaments. Five types of drainage patterns were identified: dendritic, parallel, rectangular, trellis, and modified dendritic/trellis. Interpretation and analysis of the lineaments indicate the presence of four main lineament populations that trend $\sim \mathrm{E}-\mathrm{W}, \sim \mathrm{N}-\mathrm{S}, \mathrm{NE}-\mathrm{SW}$, and NW-SE. Azimuthal distribution analysis of both the measured structures and drainage channels shows similar trends, except for very few differences in the prevailing directions. The similarity in orientation of lineaments, drainage system, and subsurface structural trends highlights the degree of control exerted by underlying structure on the surface geomorphological features. Faults and lineaments serve as a preferential conduit for surface running waters. The extracted lineaments were divided into five populations based on the main age of host rocks outcropping in the study area to obtain information about the temporal evolution of the lineament trends through geologic time. A general consistency in lineament trends over the different lithological units was observed, most probably because repeated reactivation of tectonism along preexisting deep structural discontinuities which are apparently crustal weakness zones. The reactivation along such inherited discontinuities under the present-day stress field is the most probable explanation of the complicated pattern and style of present-day landscape features in SW Jordan.
\end{abstract}

\section{Introduction}

The Levant area, in the easternmost part of the Mediterranean Sea region, is one of the most geologically complex and active regions in the world, evolving through several deformation phases (e.g., Ben-Avraham, 1989; Garfunkel, 1998; Gardosh et al., 2008; Homberg and Bachmann, 2010; Eppelbaum and Katz, 2011). This part of the Middle East lies at a complex interaction zone between three major lithospheric plates: the Arabian, African, and Eurasian plates. It consists of several distinct geologic, tectonic, and morphologic features (Fig. 1b). The most prominent feature is the Dead Sea Fault Zone (DSFZ). The

\footnotetext{
* Corresponding author.

E-mail address: o.sabbah@ymail.com (O.M.A. Radaideh).
}

DSFZ is an active plate boundary trending approximately $\mathrm{N}-\mathrm{S}$, and initiated during Miocene times as the result of the relative left-lateral movement between the African and Arabian plates (e.g., Westaway, 1994). The DSFZ extends both northward to the compressional deformation zone in the Bitlis-Zagros suture zone and southward to the extensional deformation zone along the Red Sea axis (e.g., Garfunkel, 1981; Galli, 1999). The result of deformation in the area is a number of geologic structures, such as faults, late Proterozoic dykes and shear zones that have greatly influenced rocks of various geologic ages. These structural discontinuities are often associated with linear geomorphological features such as valleys, ridgelines and slope breaks that are clearly discernible on the Earth's surface (Jordan and Schott, 2004). Remotely sensed satellite images are widely used for fast identification, extraction, and mapping of these structural lineaments (e.g., Pike, 1991; Simpson and Anders, 1992; Jordan and Schott, 2004; Hung et al., 


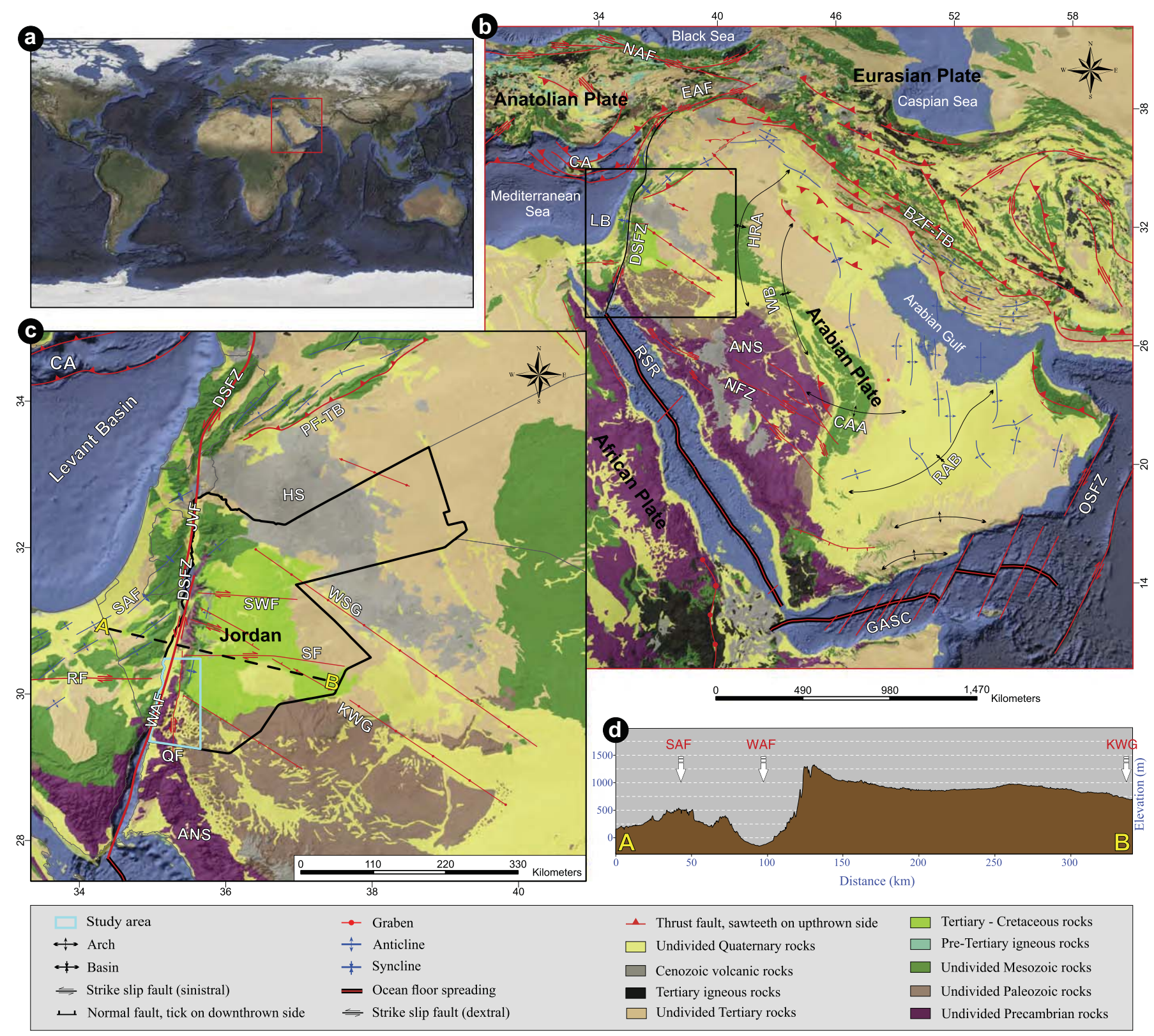

Fig. 1. Main active tectonic features of the Middle East and Eastern Mediterranean region. (a) Index map showing the location of the Middle East and surrounding areas. (b) Generalized geologic map of the Middle East region compiled from Beicip (1981), Alavi (1991), Taymaz et al. (1991), Fox and Ahlbrandt (2002), and Dilek (2009). (c) Magnification of black-rectangle area in (b). (d) Vertical change in surface elevation along transect A-B, dashed black line in (c). Geological information of the Middle East area, provided by the United States Geological Survey (USGS), was superimposed on the Blue Marble and global hill-shading images (Stockli et al., 2005; Becker et al., 2009). ANS, Arabian-Nubian Shield; BZF-TB, Bitlis-Zagros Fold and Thrust Belt; CA, Cyprian Arc; CAA, Central Arabian Arch; DSFZ, Dead Sea Fault Zone; EAF, East Anatolian Fault; GASC, Gulf Aden Spreading Center; HRA, Ha'il-Rutbah Arch; HS, Harrat Ash Shaam Basalts; JVF, Jordan Valley Fault; KWG, Karak-Wadi Al Fayha Graben; LB, Levant Basin; NAF, North Anatolian Fault; NFZ, Najd Fault Zone; OSFZ, Owen Sheba Fracture Zone; PF-TB, Palmyra Folds and Thrust Belts; QF, Quwayra Fault; RAB, Rub Al Khali Basin; RF, Ramon Fault; RSR, Red Sea Rift; SAF, Syrian Arc Folds; SF, Salwan Fault; SWF, Suwaqa Fault; WAF, Wadi Araba Fault; WB, Widyan Basin; WSG, Wadi Sirhan Graben. (For interpretation of the references to colour in this figure legend, the reader is referred to the web version of this article.)

2005; Sarp, 2005; Saadi et al., 2011; Argyriou, 2012). The identification of lineaments would be extremely difficult if it is depended only on fieldwork. Lineament mapping and analysis is, however, a significant part of neotectonic and structural geology studies since they can provide essential clues about late Quaternary tectonic deformation and environmental hazards (Panizza and Castaldini, 1987; Shake and McHone, 1987; Gabrielsen et al., 2002; Ramli et al., 2010; Masoud and Koike, 2011a, 2011b; Saadi et al., 2011; Ali, 2012).

Lineament extraction from remote sensing data can be done by both manual visualization and automatic lineament extraction using a suitable software package. The identification lineaments in the automatic technique is more efficient, more accurate, and much faster than in the manual process, which is always influenced by subjective parameters (Muhammad and Awdal, 2012). A major impediment facing automatic extraction is the inability to distinguish geological lineaments from non-geological lineaments, thus the resultant maps may contain lineament features derived from other sources besides geological structures, such as railway, power, and fence lines (Leech et al., 2003; Sarp, 2005). Although there are many studies describing the geological setting of the DSFZ, we are still lacking a clear detailed map of the distribution, extent and orientation of lineaments and their tectonic origin is not clear. In this context, an attempt was made to automatically detect and map lineaments by integrating two types of satellite data; Landsat $8 \mathrm{OLI} /$ TIRS and medium-resolution $30 \mathrm{~m}$ ASTER-GDEM images. The ASTERGDEM data were also utilized to extract drainage patterns and compile slope and flow-direction digital models (García and Camarasa, 1999; 
Turcotte et al., 2000; Robl et al., 2008; Ariza-Villaverde et al., 2015). The analysis of drainage networks helps to define geologically recent deformations (e.g., Zernitz, 1932; Ray, 1960; Ouchi, 1985; Goldsworthy and Jackson, 2000; Clark et al., 2004; Terrizzano et al., 2014), since stream channels are very sensitive to the type and orientation of geological structures (e.g., Seeber and Gornitz, 1983; Schumm and Geophysics Study Committee, 1986; Davison et al., 1998; Holbrook and Schumm, 1999; Valdiya and Rajagopalan, 2000; Schumm et al., 2002; Ribolini and Spagnolo, 2007; Maroukian et al., 2008; Shahzad et al., 2009). Anomalies identified along stream networks and profiles can provide clues to understanding structural control on the geomorphic configuration of any region at both regional and local scales (e.g., Zernitz, 1932; Ray, 1960; Seeber and Gornitz, 1983; Clark et al., 2004; Twidale, 2004). The southwestern part of Jordan is an interesting place for a such study because it is bordered by the active deformation of the Wadi Araba Fault (WAF), the southernmost segment of the DSFZ, and has excellent outcrops of a wide variety of Precambrian to Pleistocene rocks. In addition, it displays distinct geomorphological features and has a complex geodynamic evolution because its rocks have been subjected to polyphase regional tectonic deformations (Zain-Eldeen et al., 2002; Radaideh and Melichar, 2015).

Our main objective was to assess how the active tectonics of the WAF is reflected in the morphology of the landforms and development of the drainage network. For this purpose, we applied remote sensing and GIS techniques to morphological features extraction and analysis, particularly lineaments and drainage patterns, over SW Jordan. Furthermore, we investigated profiles of the main streams that drain into the Wadi Araba valley to identify morphotectonic anomalies. The location of these anomalies was then compared with the position of the lineaments/faults, seen in pan-sharpened Landsat 8 images or geological maps, in order to highlight similarities between them. Part of this research involved the collection of large numbers of ground-truth structural datasets to check whether their directions correspond to those results obtained from remote sensing data. Directional consistency between geological structures and surface morphological features can allow us to validate the control of tectonic activity on present geomorphology. Results of this study can contribute to fundamental knowledge of the neotectonic activity in the area.

\section{Geological and tectonic setting}

The study area covers an area of $8010 \mathrm{~km}^{2}$ over an altitude of $\sim 6$ to $1812 \mathrm{~m}$ asl. It has a geological record ranging from the Precambrian to Holocene. The Precambrian rocks are locally exposed in the southwesternmost part of the area and represent the oldest rocks to be found in Jordan, predominantly of late Proterozoic (Fig. 2a). These rocks form part of the late Precambrian Arabian-Nubian Shield (ANS) with rocks of different igneous and metamorphic suites (e.g., Rashdan, 1988; Jarrar et al., 2003). The ANS covers a broad area along both sides of Red Sea and represents a northern continuation of the East African Orogen (Pan-African), a voluminous addition of Neoproterozoic juvenile crust derived from the accretion of oceanic and back arcs (e.g., Duyverman et al., 1982; Vail, 1983; Stern, 1994; Kröner and Stern, 2004; Stoeser and Frost, 2005; Stern et al., 2010; Fritz et al., 2013). The exposed Precambrian rocks of the study area consist of two complexes, the older Aqaba and the younger Araba, with a regional unconformity (Saramuj conglomerate) between them. The Precambrian rocks are overlain by an incomplete Paleozoic stratigraphy with an angular unconformity, the 'Pre-Saq Unconformity' (Rashdan, 1988; Rabb'a, 1994; Ibrahim and McCourt, 1995). The incomplete and spatially variable section of the Paleozoic sequence across Jordan is a result of three stages of tilting, uplift, and erosion, which occurred in pre-Carboniferous, pre-Triassic, and pre-Cretaceous times (Powell, 1989a). The Paleozoic strata, however, is one of the most voluminous bodies of sediments in the region and consists of two main lithostratigraphic units: the Cambrian to Lower Ordovician Ram Group and the Ordovician to Silurian Khreim Group (Powell, 1989a). The Ram Group, predominantly of medium to coarse grained fluvial sandstones and siltstones with a marine carbonate/fine-grained sandstone unit, was deposited in an alluvial environment on a very gentle slope under a semi-arid to humid climate (Powell, 1989a; Amireh et al., 1994; Kolodner et al., 2006; Powell et al., 2014). The upper group is overlain by the marine Khreim Group, predominantly alternating sequences of fine to medium-grained quartzarenite and micaceous siltstone with subordinate mudstone (Powell, 1989a). The lower Palaeozoic strata are overlain unconformably by a thick sequence of Cretaceous to Eocene sediments. Devonian to Jurassic strata are missing (Bender, 1975; Bandel and Khoury, 1981; Powell, 1989b; Powell et al., 2014).

Three megasequences are recognized within the Cretaceous to Eocene sedimentary succession of Jordan; are the Kurnub Group, the Ajlun Group, and the Belqa Group (Burdon, 1959; Powell, 1989b; Powell and Moh'd, 2011). The Lower Cretaceous Kurnub group, predominantly a thick deposit of the massive white to reddish, medium to coarse-grained sandstones, was deposited in alluvial environments with an upward trend from a braided system, low and then high sinuosity alluvial plain (Bender, 1975; Powell and Moh'd, 2011). The unconformably overlying Ajlun Group consists largely of Cenomanian to Upper Coniacian shallow marine carbonates deposited on a rimmedshelf to hemi-pelagic/pelagic ramp (Powell, 1989b). The youngest megasequence (Belqa Group) unconformably overlies the Ajlun Group and represents the last marine phase. It is mainly composed of chalk, chert and phosphorite deposited in a pelagic or hemi-pelagic ramp setting (Powell and Moh'd, 2011). The remaining surface of the study area is largely occupied by the Quaternary deposits, which are mostly made up of lacustrine and alluvial sediments, fluviatile sand, gravel, and conglomerate (Bender, 1975). The tectonic setting of the area has a complex pattern of geodynamic evolution because its rocks have been influenced by multiple superimposed tectonic regimes, including the Turonian to Neogene Syrian Arc deformation and early Miocene rifting and opening of the Red Sea (Zain-Eldeen et al., 2002; Radaideh and Melichar, 2015). It is structurally bounded on the west by the active Wadi Araba fault and contains two main tectonic orientations (folds, and both strike- and dipslip faults) as inferred from mapping and field studies (Fig. 2d), NNESSW followed by NW-SE, with a secondary trend oriented $\sim$ E-W.

\section{Materials and methods}

\subsection{Remote sensing data acquisition and preparation}

The structural remote sensing analyses of the SW Jordan used two types of satellite data, optical and elevation. The optical data are from the Landsat-8 Operational Land Imager (OLI) and Thermal Infrared Sensor (TIRS). Landsat-8 OLI/TIRS is an American Earth observation satellite and the eighth satellite in the Landsat program. It collects 11 spectral bands with a spatial resolution of $30 \mathrm{~m}$ for bands 1 to 7 and 9; $15 \mathrm{~m}$ for panchromatic band (band 8); and $100 \mathrm{~m}$ for thermal bands (10 and 11). Landsat 8 OLI/TIRS data used in this work were from pathrow numbers 174-39 and 174-40 scenes of the WRS-2, acquired on 23th May 2015, and were downloaded from the United States Geological Survey (USGS) Global Visualization Viewer (GLOVIS) portal (http:// earthexplorer.usgs.gov/). The scenes were reprojected from Universal Traverse Mercator (UTM Zone 36N and 37N) in WGS 84 Datum to geographic coordinate system (lat/long). The pairs of Landsat scenes were mosaicked to form a single scene covering the area. Once the mosaic was completed, the full scene was clipped to fit the study area boundary. All preprocessing was implemented using PCI Geomatrica v12.

The Elevation data used in this study were obtained from the Advanced Spaceborne Thermal Emission and Reflection Radiometer (ASTER) Global Digital Elevation Model (GDEM). ASTER-GDEM was released in 2009 by the Japanese Minister of Economy, Trade and Industry (METI) and the United States National Aeronautics and Space Administration (NASA). The ASTER-GDEM is in GeoTIFF format with geographic 


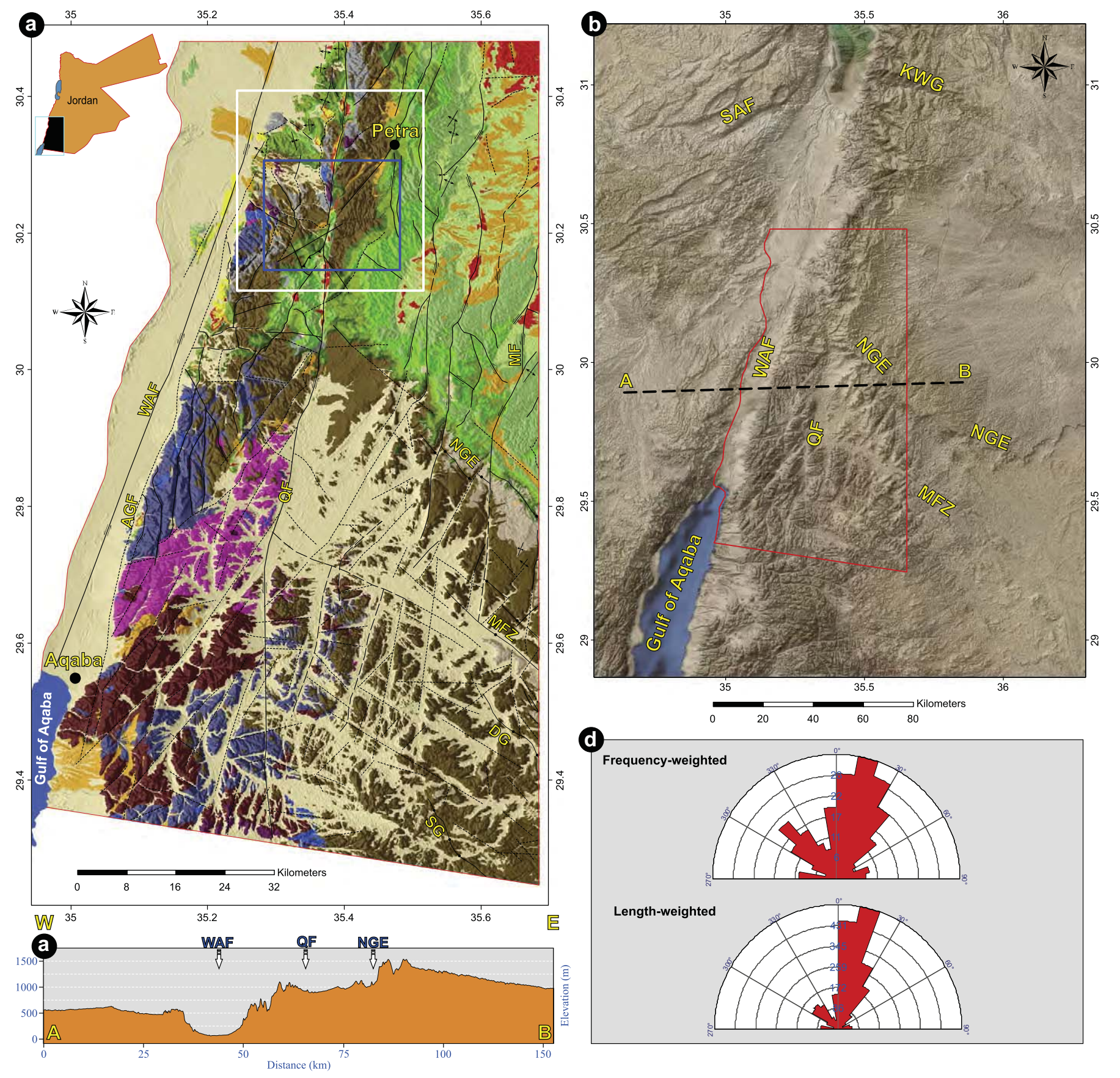

\begin{tabular}{|c|c|c|}
\hline Legend & Holocene - Recent (sands and wadi sediments) & Ordovician - Silurian (Khreim sandstones) \\
\hline - City & Pleistocene sediments & Cambrian - Ordovician (Ram sandstones) \\
\hline$\checkmark$ Thrust & Oligocene - Miocene (Safi conglomerate) & Precambrian (Volcanic rocks) \\
\hline$\bullet$ Graben & Eocene (URC) & Precambrian (Fainan granitic rocks) \\
\hline$\uparrow$ Anticline & Maastrichtian - Paleocene (MCM) & Precambrian (conglomerates) \\
\hline * Syncline & Campanian - Maastrichtian (ASL / AHP) & Precambrian (Yutum granitic rocks) \\
\hline -..-- Fault, inferred & Santonian (WG) & Precambrian (Urf prophyritic rocks) \\
\hline$\rightleftharpoons$ Strike slip fault (dextral) & Cenomanian - Coniacian (Ajlun carbonates) & Precambrian (Granodiorite / Monzogranite rocks) \\
\hline$\leftrightharpoons$ Strike slip fault (sinistral) & Lower Cretaceous (Kurnub sandstones) & Precambrian (Metamorphic rocks) \\
\hline
\end{tabular}

Fig. 2. Location of the study area. (a) Generalized structural and geological map of the southwestern part of Jordan. (b) Digital elevation model shaded relief image showing a regional aerial view of the northwestern part of the Arabian plate and location of the study area. (c) Topographic profile of transect along dashed black line A-B in (b). (d) Frequency and length-weighted rose diagrams showing azimuth statistics of previously mapped faults, fractures, and folds in SW Jordan. Geological information provided by the Geological Mapping Division of the Jordanian Ministry of Energy and Mineral Resources. AGF, Aqaba-Gharandal Fault; AHP, Al Hisa Phosphorite Formation; ASL, Amman Silicified Limestone Formation; DG, Dubaydib Graben; KWG, Karak-Wadi Al Fayha Graben; MCM, Muwaqqar Chalk Marl Formation; MF, Ma'an Fault; MFZ, Mudawwara Fault Zone; NGE, Ras en Naqab-Batn Al Ghoul Escarpment; QF, Quwayra Fault; SAF, Syrian Arc Folds; SG, Saladih Graben; URC, Umm Rijam Chert Limestone Formation; WAF, Wadi Araba Fault; WG, Wadi Umm Ghudran Formation. (For interpretation of the references to colour in this figure legend, the reader is referred to the web version of this article.) 
lat/long coordinates and a 1 arc-second ( $30 \mathrm{~m}$ ) grid of elevation. The study area is partly covered by three tiles of ASTER GDEM:

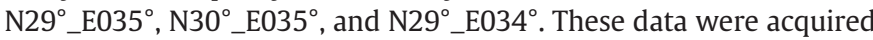
on 17th October 2011 and were downloaded from the website of the Japan Space Systems (http://www.jspacesystems.or.jp/). The individual ASTER-GDEM tiles were mosaicked into one large image using ArcGIS 10.0. The mosaicked raster file was later resized to the exact coordinates of the study area. The resulting DEM image provides the basis to create hill-shaded images, and to extract lineaments as well as stream networks.

\subsection{Digital processing for linear feature identification}

Hill-shaded images derived from ASTER-GDEM and both bands 7 and 8 of landsat 8 scenes were used to map the lineaments in the study area. Analytical hill-shading techniques are widely used in tectonically active regions for the recognition of linear features with particular orientations (e.g., Pike, 1991; Simpson and Anders, 1992; Deffontaines et al., 1997; Jordan and Schott, 2004; Abarca, 2006; Arrowsmith and Zielke, 2009; Masoud and Koike, 2011a, 2011b; Argyriou, 2012; Langridge et al., 2013). Analytical hill-shading is used to depict the topographic relief of the Earth's surface. It is generally based on simulating the effect of artificial light arriving from a point source of illumination with specified altitude and azimuth (e.g., Batson et al., 1975; Horn, 1981). Depending on the illumination azimuth and tilt chosen, features are either obscured or highlighted in a hill-shaded image. Features parallel to the light beam are generally not identified as easily as those oriented perpendicularly to the illumination (Simpson and Anders, 1992; Cooper, 2003; Abdullah et al., 2010; Muhammad and Awdal, 2012). This bias can be illustrated by the application of different sun azimuth values to the hill-shaded image derived from ASTER-GDEM for a part of the study area (Fig. 3). A visual inspection of these hill-shaded images clearly shows that some of the linear features identified at one azimuth angle of the light source are not apparent or are poorly visible at another angle.

In an attempt to overcome the limitations of the lighting effect on the appearance of linear features, a multi-directional oblique-weighted (MDOW) shaded relief method (Mark, 1992) was adopted to generate a hill-shaded image illuminated from different azimuth angles of the light source. The method represents a combination of hill-shaded models illuminated from four different azimuth angles $\left(225^{\circ}, 270^{\circ}, 315^{\circ}\right.$, and $360^{\circ}$ ) and weighted using a generalized aspect map. For this purpose we employed the MDOW hill-shade function within DEM Surface Tools for ArcGIS (Jenness, 2013), to generate two multi-illumination hill-shaded images with a light azimuth covering a range of $135^{\circ}$ and a light elevation of $45^{\circ}$ (the ArcGIS default). The first multi-illumination hill-shaded image resulted from combining four hill-shaded models illuminated from $0^{\circ}, 45^{\circ}, 90^{\circ}$ and $135^{\circ}$ light azimuths. The second multi-illumination hill-shaded image was produced by combining the other four hill-shaded models with light azimuth angles of $180^{\circ}, 225^{\circ}$, $270^{\circ}$ and $315^{\circ}$. Both images were then used for automatic lineament extraction. The aim of this procedure was to ensure that the lineaments generated from two hill-shaded images with different light azimuth combinations were comparable. Combining different lighting azimuth angles together into a single image provides valuable insight into the different spatial patterns of the linear features that would not be visible if only a single lighted hill-shaded image was used (e.g., Mark, 1992; Onorati et al., 1992; Loisios et al., 2007; Abdullah et al., 2009, 2010). For a comparative analysis and complementary lineament detection approach, the identification of lineaments was also carried out on both band 7 and the panchromatic band (band 8 ) of Landsat 8 scenes. Use of band 7 with a spatial resolution $30 \mathrm{~m}$ is helpful for lithological and lineament discrimination (e.g., Suzen and Toprak, 1998). The panchromatic band 8 with a ground resolution of $15 \mathrm{~m}$ provides a large amount of useful information for geological lineament discrimination, and can improve the detectability of certain small features that are not clear in the much coarser resolution satellite images (e.g., Ricchetti and Palombella, 2007). The use of the two bands, together or separately, for automatic lineament detection is reported in several studies (e.g., Hung et al., 2005; Sarp, 2005; Qari et al., 2008; Bishta, 2009; Mogaji et al., 2011; Bishta et al., 2014; Ibrahim and Mutua, 2014).

LINE module in the PCI Geomatica v12 software package was applied in this study to extract lineaments from the datasets listed above. The lineament extraction module consists of three stages: edge detection, thresholding and curve extraction (PCI Geomatics, 2015). The tool extracts curvilinear features from a single image channel and records the polylines in a vector layer by using six threshold parameters, explained briefly elsewhere (Sarp, 2005; PCI Geomatics, 2015). The input parameters were modified until the desired lineament identification was obtained. The resulting lineament map, however, contains only straight lines. The following input parameters were generally used and are mostly reported in both the software user's manual (PCI Geomatics, 2015) and many recent studies (e.g., Hung et al., 2005; Abdullah et al., 2009, 2010; Hubbard et al., 2012), which have successfully used the same PCI Geomatica software: RADI (Filter Radius) $=24$; GTHR (Edge Gradient Threshold) $=70$; LTHR (Curve Length Threshold) $=30$; FTHR (Line Fitting Threshold) $=3$; ATHR (Angular Difference Threshold $)=7$; and DTHR (Linking Distance Threshold) $=70$. The four automatically extracted lineament maps obtained from the LINE model in PCI were loaded into ArcMap software and stored in separate accompanying GIS shapefiles for further interpretation and analysis. Lineaments that matched artificial features, i.e. pipelines, roads and rail lines, were removed during visual inspection. The numerical values of azimuth and length for each lineament dataset were calculated in an ArcGIS extension tool, EasyCalculate 10 (Tchoukanski, 2015). For each lineament dataset, a frequency-weighted rose diagram was created to determine the dominant azimuth frequency of lineaments. Determination of the dominant trend direction based on lineament frequency may not always be correct. This can be explained by the fact that the automatically extracted lineaments are usually short in length, and many individual lines may represent a single long lineament. This in turn may lead to a greater concentration of specific lineament directions at the expense of the others, and this will have a direct effect on the determination of the dominant trends. In order to avoid bias in dominant trend identification, length-weighted rose diagram for each lineament dataset gathered were also created. Ricchetti and Palombella (2007) and Aubry et al. (2011) suggested that rose diagrams based on lineament length are more reliable than those based on frequency, because lineaments are usually detected at different scales so that their lengths are highly variable. A comparison between all lineament datasets gathered was performed to create the final lineament map. Finally, lineaments in the final map were evaluated with regard to their strike, length, and density. Lineaments orientation and length of the final map were charted on rose diagrams for directionality analysis. Lineament density is useful for understanding the spatial distribution of lineaments (Kumar and Reddy, 1991; Lee and Lee, 2015).

\subsection{Delineation of drainage networks}

In tectonically active regions, drainage networks are often strongly influenced by the type and orientation of geological structures (e.g., Davison et al., 1998; Holbrook and Schumm, 1999; Schumm et al., 2002; Ribolini and Spagnolo, 2007; Maroukian et al., 2008; Shahzad et al., 2009). They represent local anomalous deviations from the expected drainage patterns, and are helpful in the recognition of neotectonic activity in different tectonic settings. They thus serve as important elements for tectonogeomorphological analysis (e.g., Burrato et al., 2003; Clark et al., 2004; Vannoli et al., 2004; Shahzad et al., 2009). In the last two decades, the automatic identification of drainage networks and drainage basins from DEMs has become increasingly popular through the use of various GIS software packages (García and Camarasa, 1999; Turcotte et al., 2000; Robl et al., 2008; Bahrami, 2013; Ariza-Villaverde 

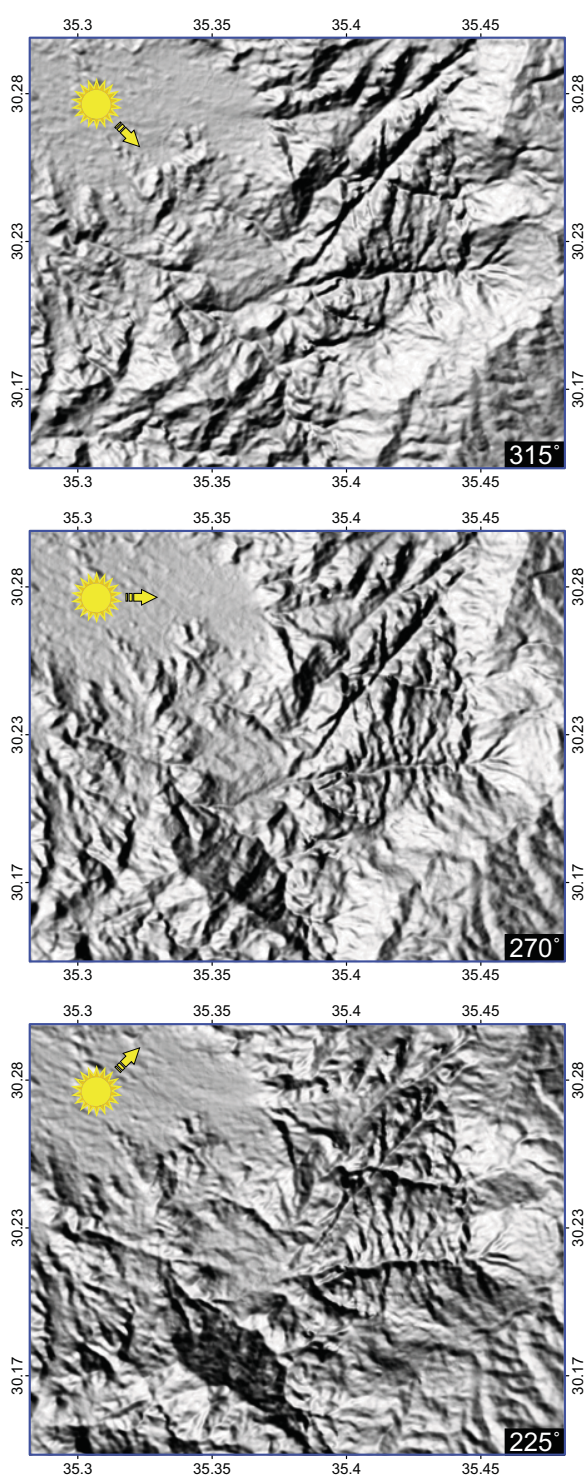
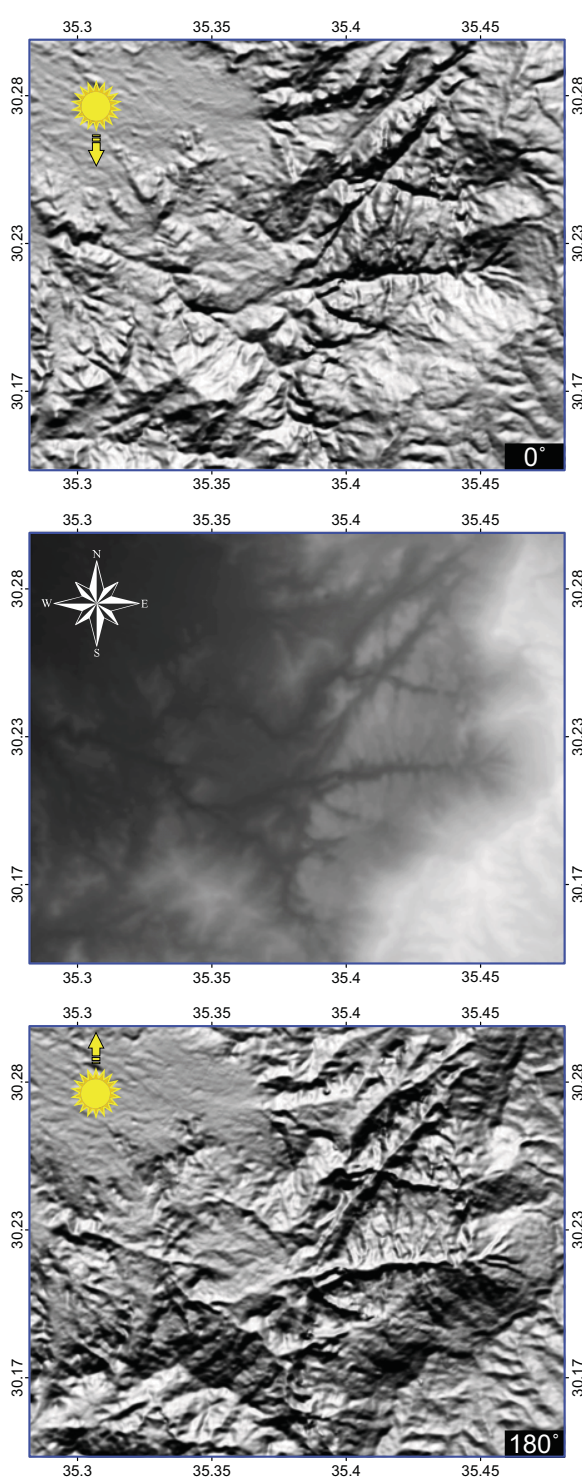
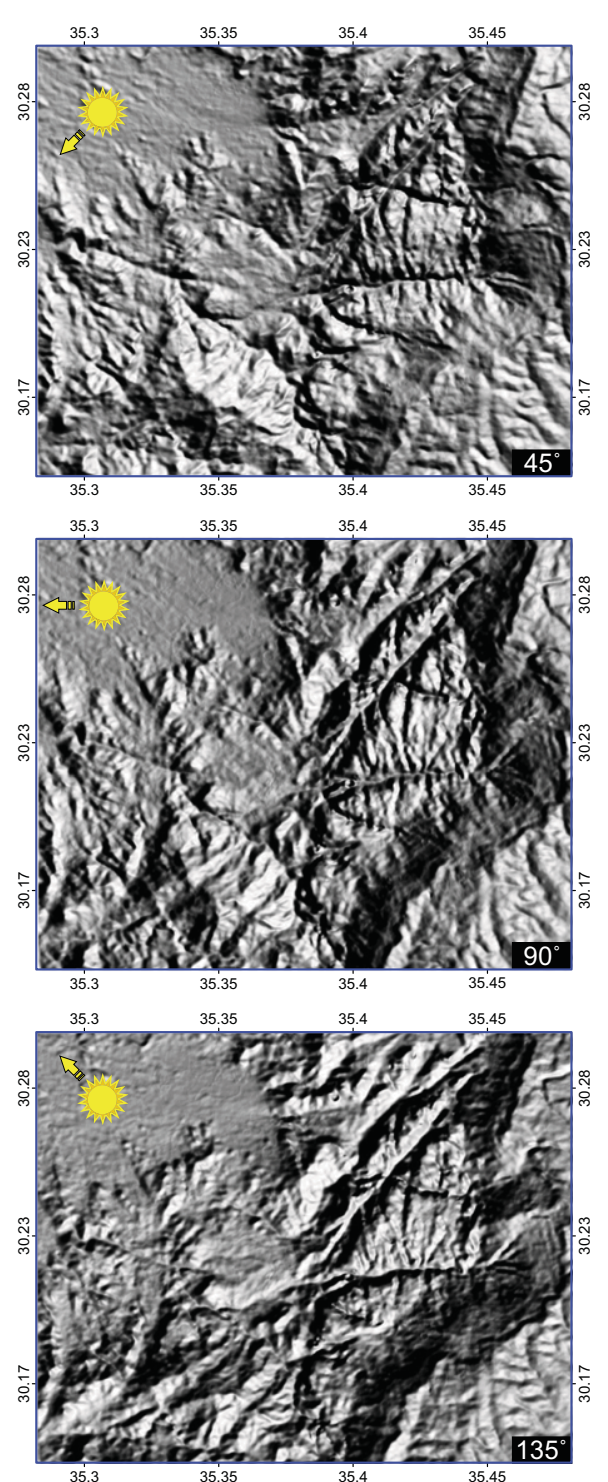

Fig. 3. Hill-shaded images with a constant light dip of $45^{\circ}$ and various light azimuths, covering part of the study area (blue rectangular box in Fig. 2a), produced from the same ASTERGDEM data. The visibility of the linear structure varies greatly according to the change in azimuth of the light source. Linear features striking perpendicularly or obliquely to the look direction of the light sources were easy recognized, whereas those parallel to the look direction are suppressed. (For interpretation of the references to colour in this figure legend, the reader is referred to the web version of this article.)

et al., 2015; Gürbüz et al., 2015). Several studies highlighted the effect of DEM resolution on the accuracy of hydrologic modelling and associated drainage networks (Garbrecht and Martz, 1994; Zhang and Montgomery, 1994; Cotter et al., 2003; Chaubey et al., 2005; Hosseinzadeh, 2011; Sharma et al., 2011; Azizian and Shokoohi, 2014). DEMs of different resolutions have the potential to significantly affect watershed and stream network delineation. Decreasing the resolution of a DEM generally tends to reduce accurate representation of watershed areas and slope gradients.

Arc Hydro Toolset 2.0, an extension for ArcGIS 10.0 developed by Esri (2011), has been commonly used for DEM preprocessing and stream network delineation. It consists of several functions that provide a basic database design for water resources applications. This includes DEM-based watershed delineation, network generation, and attributebased tracing (Shamsi, 2008; Esri, 2014). The drainage network and basins of the study area were extracted from the $30 \mathrm{~m}$ resolution ASTERGDEM by using the Arc Hydro package. Our extraction of the drainage systems was carried out in a multi-step process including sink filling, identification of flow direction, calculation of flow accumulation, stream definition and segmentation. This procedure for the automatic delineation of drainage systems described in detail elsewhere (ESRI, 2011).

The most important step in the procedure is to set the number of grid cells that are used to define streams. Low value thresholds lead to an increase in the level of detail of the stream networks. We could not find any information in the literature regarding how to set this value so we checked threshold areas with $250,500,1000,1500,2000$, and 3000 grid cells for the delineation of drainage networks in the study area. This was to ensure that the stream networks generated from different threshold values are comparable. For directional analysis, each channel network was split into several segments based on their orientations using the 'Split Line At Vertices' tool from 'Data Management Tools' in ArcGIS toolbox. This was because the extracted drainage channels are mostly sinuous because of the complex topography and surface heterogeneities of the study area. The properties of orientation and length for each drainage channel segment were calculated using spatial GIS operations. These properties were then charted on rose diagrams to highlight preferred orientations of water flow over the surface of the area. Drainage density, which is a measure of the total length of stream 

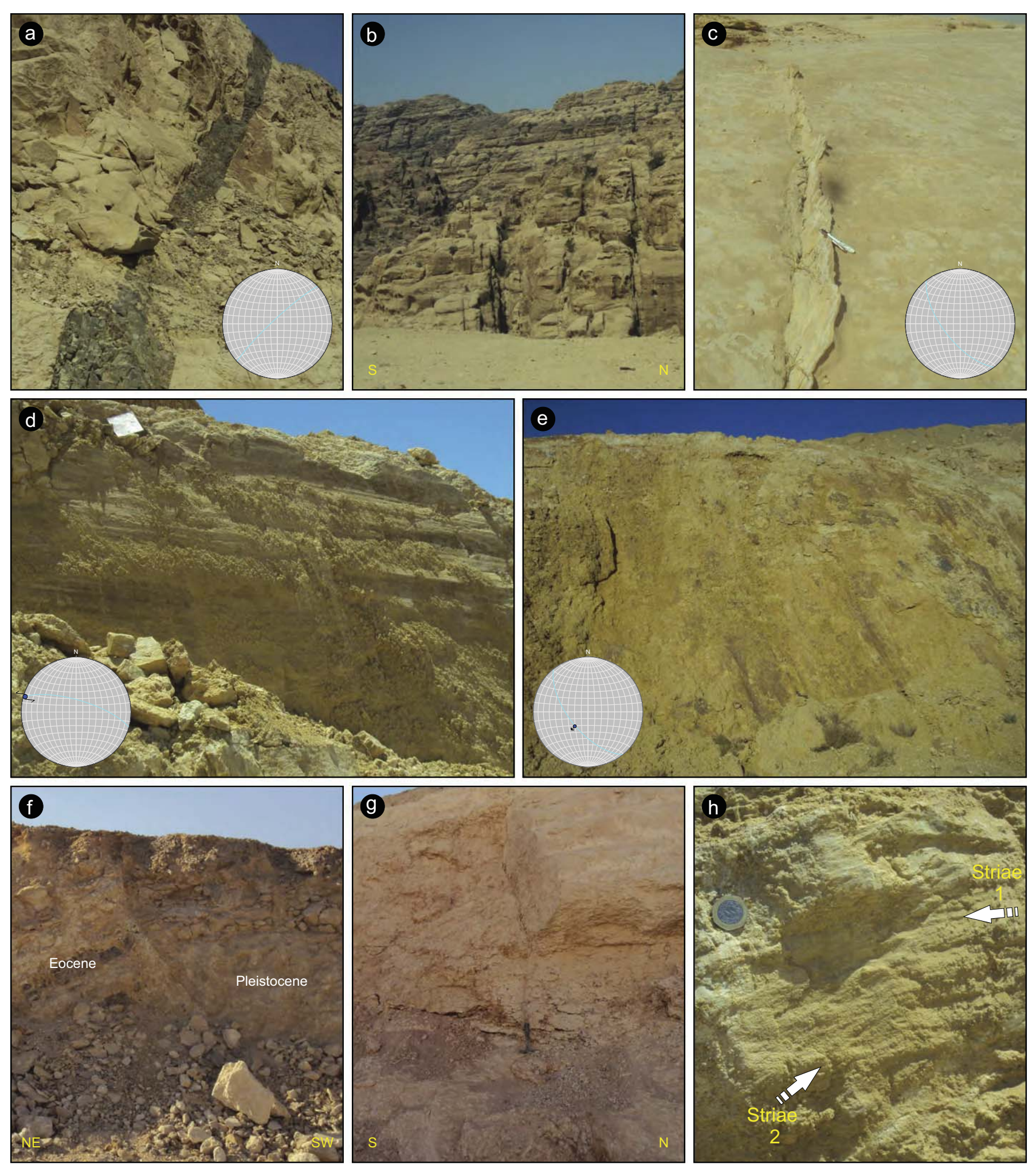

Fig. 4. Examples of brittle structures observed in the field area. (a) A sub-vertical dyke, striking NE-SW, crosses Precambrian complex rocks. (b) Multi-scale fracture sets in the CambroOrdovician siliciclastic strata. (c) A steeply dipping deformation band, trending NW-SE, in the Cambro-Ordovician succession. (d) E-W oriented sub-vertical sinistral strike-slip fault plane with sub-horizontal striae cutting the Cenomanian Na'ur Limestone formation. (e) Steeply dipping normal fault plane, striking NW-SE, with very pronounced striae cutting the Cenomanian Na'ur Limestone formation. (f) and (g) Stratigraphic evidence of Quaternary faulting. (h) Fault surface covered by two superimposed sets of striae, indicating multiple events of tectonic deformation.

Fig. 5. Multi-illumination hill-shaded images generated from the $30 \mathrm{~m}$ ASTER-GDEM using a $45^{\circ}$ light source altitude. (a) Multi-illumination hill-shaded image resulted from combining four hill-shaded models with the azimuth angles of the light source of $0^{\circ}, 45^{\circ}, 90^{\circ}$ and $135^{\circ}$. (b) Multi-illumination hill-shaded image resulted from combining four hill-shaded models with light source azimuths of $180^{\circ}, 225^{\circ}, 270^{\circ}$ and $315^{\circ}$. By this approach the deficiencies associated with single lighted hill-shaded images have been removed, thus the major relief features present in the area are highlighted and enhanced from four directions. The study area is generally characterized by (c) a sequence of negative relief features and (d) positive relief features. 

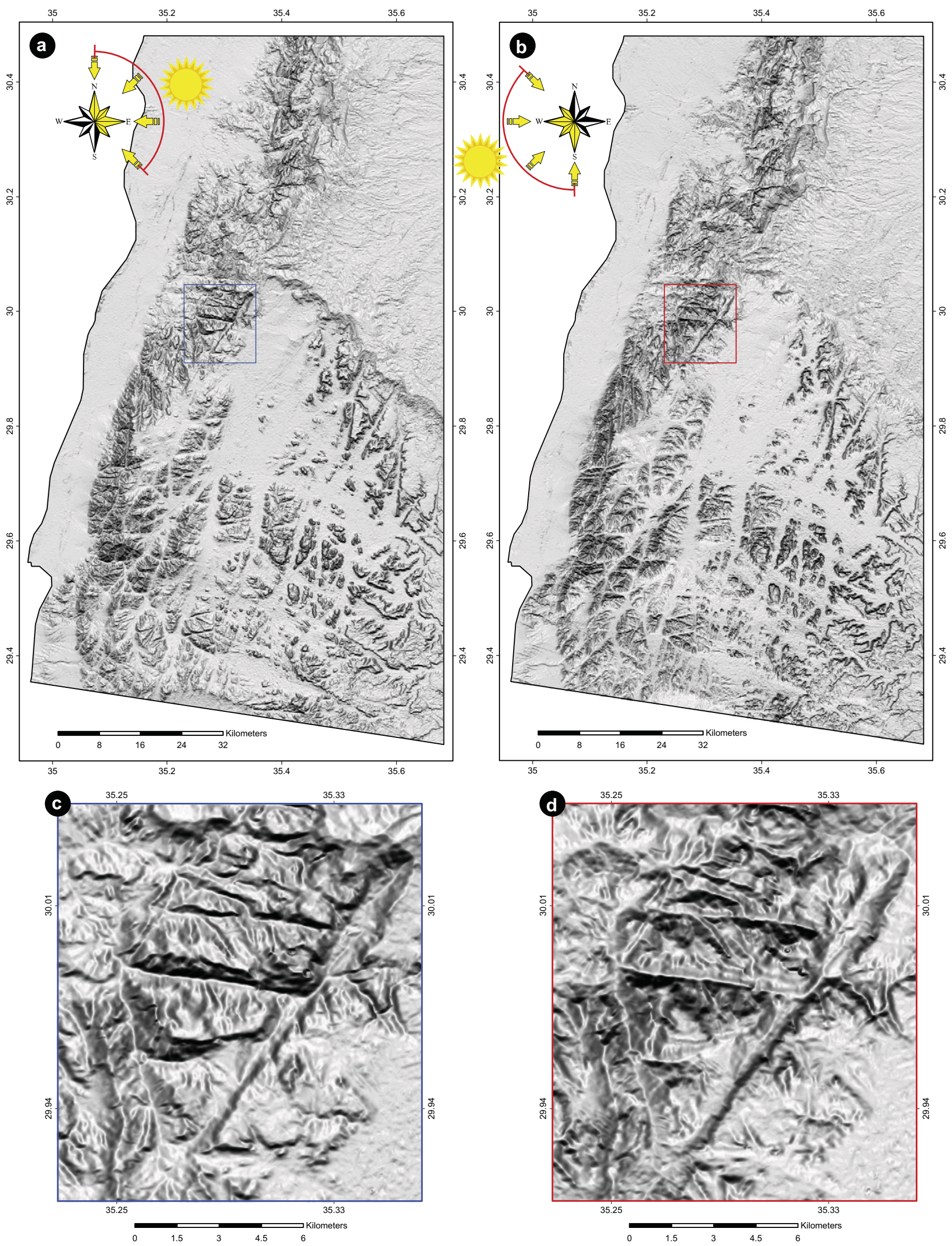

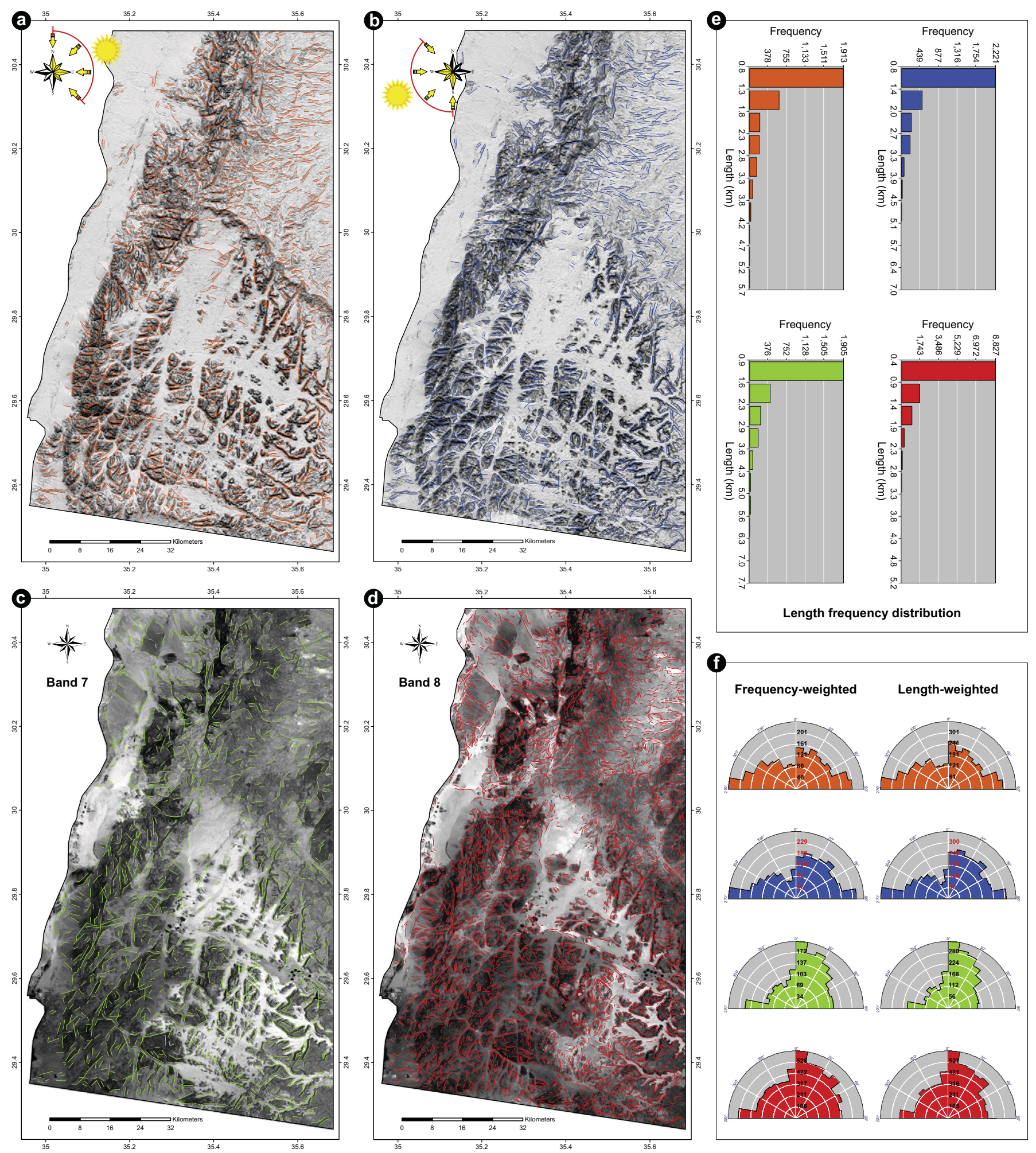

Fig. 6. Distribution of lineaments derived automatically from (a) multi-illumination hill-shaded image with the light source azimuth of $0^{\circ}, 45^{\circ}, 90^{\circ}$ and $135^{\circ}$; (b) multi-illumination hillshaded image with the light source azimuth of $180^{\circ}, 225^{\circ}, 270^{\circ}$ and $315^{\circ}$; (c) band 7 of Landsat 8 with $30 \mathrm{~m}$ resolution; and (d) band 8 (panchromatic) of Landsat 8 with $15 \mathrm{~m}$ resolution. The extracted lineaments are concentrated in areas of higher rate of change in surface topography, but are relatively absent in the central and western parts of the study area, which have generally flat topography and an extensive cover of sand dunes. (e) Length-frequency distributions for each of lineament data set. (f) Frequency and length weighted-rose diagrams showing the dominant azimuth directions for each lineament population. The lineaments extracted from different types of data sources reveal that the major trends of lineaments in the study area are $\sim \mathrm{E}-\mathrm{W}, \sim \mathrm{N}-\mathrm{S}, \mathrm{NE}-\mathrm{SW}$, and NW-SE. (For interpretation of the references to colour in this figure legend, the reader is referred to the web version of this article.)

per unit area, was calculated to extract further information on the spatial distribution of drainage channels over the area.

In order to assess whether channel networks are shaped or influenced by active tectonics in the study area, the spatial correlation between stream segments and lineaments as well as gradient variations along stream long profiles needs to take into account. To attempt to determine the location of lineament traces and lithological variations that could potentially influence parts of the drainage channels, we need a 
high accuracy Landsat image. We achieved this by combining the higher-resolution panchromatic band 8 (spatial resolution of $15 \mathrm{~m}$ ) with selected lower-resolution multispectral bands (spatial resolution of $30 \mathrm{~m}$ ) to improve the spatial resolution of the Landsat 8 satellite imagery (Fig. $S 1$ in the supplementary material available online). The latter procedure is known as pan-sharpening technique and is most widely used for improved geological and environmental information extraction (e.g., Schetselaar, 2001; Al Rawashdeh et al., 2006; Pavlic et al., 2008; Zhang, 2008; Abdallah, 2010; Argyriou, 2012). Using the DEM and its derived slope, we conducted longitudinal profile analyses for five streams or channels, with lengths ranging from 25 to $34 \mathrm{~km}$, which flow on the eastern side of the Wadi Araba rift valley and cross a strong topographic transition between the low-gradient uplands and the deeply incised mountain front on the west side of Jordan (Fig. S1). The obtained longitudinal profiles show the latitude, longitude, elevation, and slope values for the representative stream interval defined by the user. A constant horizontal distance with an interval of $10 \mathrm{~m}$ was used for all studied streams, using ArcGIS Spatial Analyst and Hawth Tools v.3.27 extension (Beyer, 2004).

\subsection{Field data collection}

Field work was conducted at 36 locations where significant exposed fault ruptures, deformation bands (DBs), and late Proterozoic dykes are present. The sites investigated were fresh outcrops along road exposures and natural outcrops of various geologic ages. Each site was located with a global positioning system (Garmin GPSmap 76Cs). The purpose of the field work was to provide an overview of groundtruthing data (compass measurements) undertaken to validate whether the lineaments analysis results are reflected precisely on the ground. Field analysis included the measuring of strike and dip of fault/fracture planes, DBs, and dykes (Fig. 4), and a determination of the dominant direction in each exposure. Particular attention was paid not only to determine a dominant trend but also to find all possible fault orientations to assess total diversity. The orientations data were measured using a geological stratum compass. The orientation data are displayed on rose diagrams and lower-hemisphere equal-area projection plots of poles to determine dominant orientations.

\section{Analysis and results}

\subsection{Lineaments analysis}

Two multi-illumination hill-shaded images were created by combining various light azimuths together (Fig. 5). From the figure, it is clear that surface relief features with different directions are revealed, and display a sequence of positive and negative elements. The negative relief features (Fig. 5a,c) mostly represents faults, valleys, trenches, and joints. Positive relief elements represents elevated topography (Fig. 5b,d), e.g. topographic ridges, and scarps. Four sets of lineament GIS shapefiles were automatically mapped using the two hill-shaded images with combining variable light angles, and both bands 7 and 8 of the landsat 8 scene (Fig. 6a-d).

The basic statistics for each lineament population are given in Table 1. In addition, a length-frequency distribution diagram as well as frequency and length weighted rose diagrams for each lineament population were created (Fig. 6e,f). Both multi-illumination hill-shaded images produce very similar results (Table 1 and Fig. 6e,f). It also shows that the lineaments obtained from band 8 are smaller and have much higher densities than those identified on both the two hill-shaded images and band 7 of landsat 8 (Fig. 6e). This is probably because band 8 has a higher spatial resolution $(15 \mathrm{~m})$ than other images $(30 \mathrm{~m})$, which can easily lead to detection of numerous small lineaments. However, the quality of extracted lineaments depends mainly on the spatial resolution of the imagery; higher resolution imagery permits a more detailed detection of linear features (e.g., Hung et al., 2005; Prasad et al., 2013). An apparent tendency for a higher concentration of lineaments is observed over regions of high rugged topography and complex geological settings, which is particularly the case in the areas of the Precambrian to early Palaeozoic age. On the other hand, in the central and western parts of the study area, lineaments are generally rare and scattered in various directions (Fig. 6a-d). This is not surprising, because the lineaments in these parts are covered by thick deposits of windblown sand and other recent sediments.

Rose diagrams in Fig. 6f, summarizing the dominant azimuth directions for each lineament population based on both frequency and cumulative-length weighting, clearly show that the azimuth direction statistics of the lineaments obtained from two multi-illumination hillshaded images follow the same pattern. The same observation can be also made for the two sets of lineaments derived from two different bands of Landsat 8 . The frequency and length-weighted rose diagrams derived from the two different hill-shading images show three main orientations: E-W, N-S, and NE-SW. Both sets of lineaments derived from the two different bands of Landsat 8 are similar, showing the N$\mathrm{S}$ trend followed by an E-W trend, with a secondary trend oriented NW-SE. They differ, however, in that another main direction was identified for lineaments from the band 8 image, N45E compared with N25E derived from band 7. In order to obtain a general view of spatial distribution of the lineaments through the whole area, lineaments derived from two different types of data (Landsat 8 and DEM images) were combined. Accordingly, all the lineaments derived from both band 8 and a shaded relief image with combining light angle of $180^{\circ}, 225^{\circ}, 270^{\circ}$ and $315^{\circ}$ were compiled into a single shapefile using the merge tool of ArcGIS software. A simplified process was applied to remove redundant and duplicate lineaments by using the cleaning functions (v.clean toolkits), implemented within GRASS GIS v.7 software (GRASS Development Team, 2015). As a result, 7965 lineaments were identified, ranging in length from 0.43 to $8.619 \mathrm{~km}$, with a total length of $10,341.1 \mathrm{~km}$ (Fig. 7a). An orientation analysis of these lineaments indicates the presence of three main trends oriented $\sim \mathrm{N}-\mathrm{S}, \sim \mathrm{E}-\mathrm{W}$, and NESW through the whole area, with a secondary trend oriented NW-SE (Fig. 7c). These trends are visible in the lineament density map of the area (Fig. 7b). The highest concentration of $\sim \mathrm{N}-\mathrm{S}$ lineaments is in the north and east central portion of the study area (Fig. 7b). The regions characterized by high densities of $\sim \mathrm{E}-\mathrm{W}$ lineaments are the northeast and southwest corners, west central and north central portions of the study area. The highest concentration of NE-SW lineaments is mainly restricted in the west central parts of the area. The highest NW-SE lineament density is observed in the south central portion of the study area.

Table 1

Statistical summary of the automatic lineament maps. Band 8 generally reveals significant additional details about the lineament extraction that were not apparent in the other much coarser datasets.

\begin{tabular}{|c|c|c|c|c|}
\hline \multirow{2}{*}{ Character } & \multicolumn{2}{|c|}{ Multi-illumination hill-shaded images } & \multicolumn{2}{|l|}{ Landsat 8} \\
\hline & $\left(0^{\circ}, 45^{\circ}, 90^{\circ}\right.$ and $\left.135^{\circ}\right)$ & $\left(180^{\circ}, 225^{\circ}, 270^{\circ}\right.$ and $\left.315^{\circ}\right)$ & (Band 7) & (Band 8) \\
\hline No. lineaments & 2573 & 2649 & 2219 & 8051 \\
\hline Min. length (m) & 0802 & 0803 & 0865 & 0430 \\
\hline Max. length (m) & 6979 & 8619 & 9344 & 6765 \\
\hline Total length $(\mathrm{km})$ & 3911.7 & 3938.8 & 3261.9 & 7325.8 \\
\hline
\end{tabular}



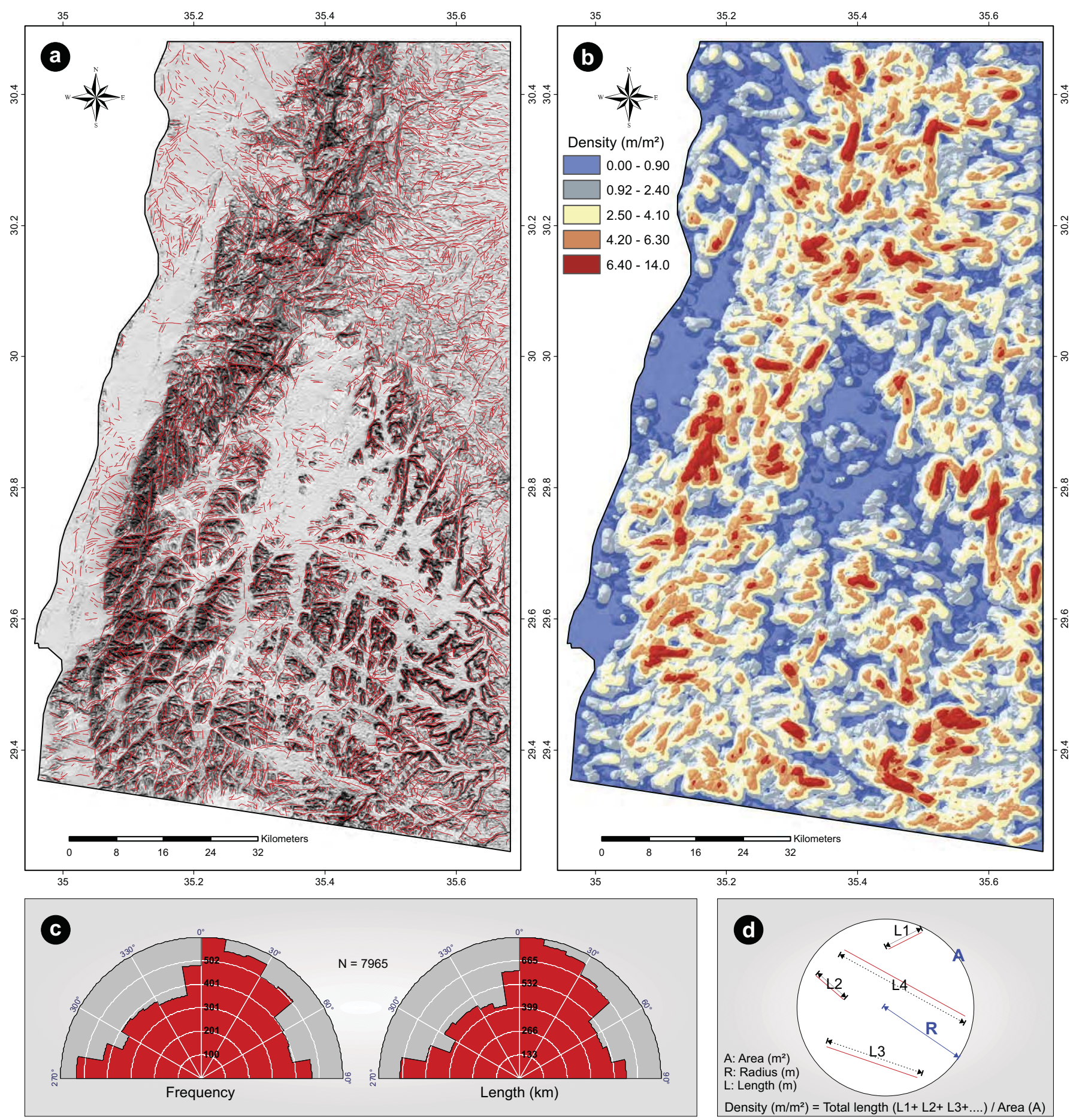

Fig. 7. Final lineament map generated by the combination of all lineaments automatically derived from both band 8 and a multi-illumination hill-shaded image with the light source azimuth of $180^{\circ}, 225^{\circ}, 270^{\circ}$ and $315^{\circ}$. (a) Lineament traces map of the study area indicating several intersecting sets with various length and orientation. (b) Lineament density map with a search radius of $1 \mathrm{~km}$. The zones of maximum lineament density anomalies probably indicate a higher intensity of deformation. The central and central-western portion of the entire area has fewer lineaments than other parts. This can be attributed mainly to the thick covering of sand dunes which do not allow the lineaments to emerge at the surface. (c) A frequency and length weighted-rose diagrams of all 7965 lineaments showing three main lineament populations trending $\sim \mathrm{N}-\mathrm{S}, \sim \mathrm{E}-\mathrm{W}$, and NE-SW directions, with a secondary trend oriented NW-SE. (d) Illustration of lineament density analysis. (For interpretation of the references to colour in this figure legend, the reader is referred to the web version of this article.)

\subsection{Drainage networks}

Applying the analysis methodology to the DEM and its associated flow direction grid enabled us to trace the drainage networks and their associated drainage basins. Fig. 8 provides examples of drainage networks extracted from the DEM with different threshold values. The figure illustrates that the use of a small threshold value can derive a more detailed delineation of the drainage network while a bigger threshold area can only give a general view. The use of a small threshold area is applicable only to high resolution DEMs. Any attempt to use a small threshold area with a low resolution DEM will give inaccurate drainage networks, especially when the drainage network is dense (e.g., Ribolini and Spagnolo, 2007; Ariza-Villaverde et al., 2015). However, the distribution of azimuth directions for the drainage networks at 

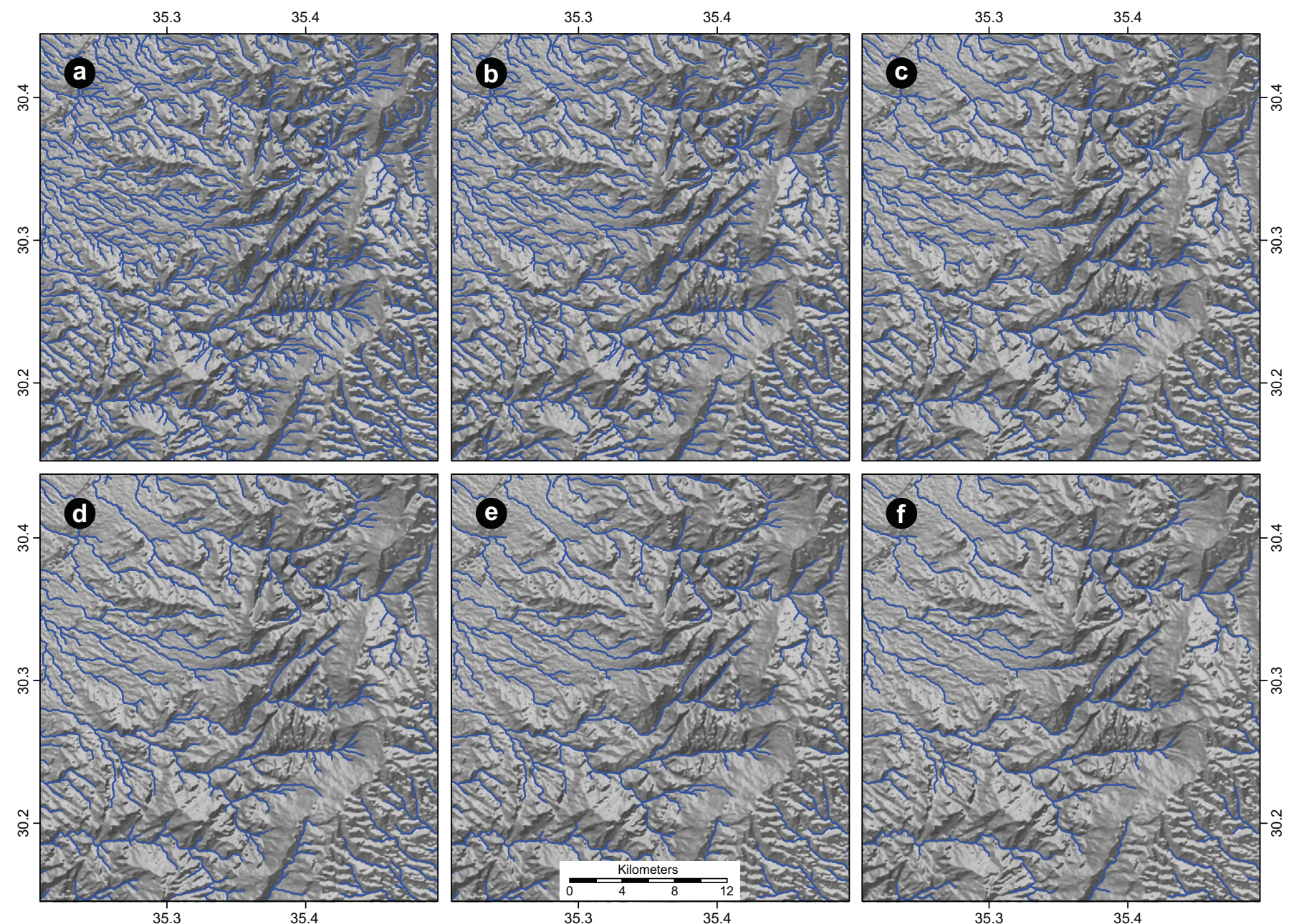

Fig. 8. Portion of the study area (white rectangular box in Fig. 2a) showing the delineated stream networks with different threshold values: (a) 250 , (b) 500, (c) 1000, (d) 1500, (e) 2000, and (d) 3000 grid cells, superimposed on the flow direction map.

various threshold levels was not significantly different. Considering the size of the study area $\left(8010 \mathrm{~km}^{2}\right)$, we decided to use an accumulation threshold of 500 DEM cells (about $0.45 \mathrm{~km}^{2}$ ) as the criterion. This was sufficient to provide drainage networks with considerably less noise and error. In total, 53,880 segments of 10,203 channels with a total of $9548 \mathrm{~km}$ of stream length, covering a total area of $8010 \mathrm{~km}^{2}$ were analyzed in this study (Fig. 9a). Channel segment analysis by means of frequency and length-weighted rose diagrams (Fig. 9c) shows that streams flow along four prominent trends, NE-SW, N-S, $\sim \mathrm{E}-\mathrm{W}$, and NW-SE. The spatial distribution of drainage density (Fig. 9b) shows that the highest concentration of northeast drainage channels is in the central and northeastern parts of the area. It also shows that the highest density of NW-SE channels is in the northwest corner, west and south central portion of the study area. The $\sim \mathrm{E}-\mathrm{W}$ trending channels are mainly in the northwest, northeast and southwest corner, and also in the westcenter of the study area. However, the most notable feature of the map is the high concentrations of drainage along the Dead Sea Fault (DSF), in the western part of the whole study area. Drainage patterns of the study area consist mainly of dendritic, parallel, trellis, rectangular, and modified dendritic/trellis types (Fig. 9e-i).

\subsection{Field data analysis}

A total of 2344 faults, 326 DBs, and 55 dykes were measured from 36 locations on different lithologies distributed in three sub-areas (Fig. 10a). Petra, Ras en-Nagab, and Aqaba. A variety of fault strikes has been recorded with offsets from centimeters to as much as a few meters, with NW-SE, $\sim \mathrm{E}-\mathrm{W}, \mathrm{NE}-\mathrm{SW}$, and N-S trends (Fig. 10b). Most of them are characterized by moderate to very steep inclined planes that have horizontal to sub-horizontal plunging striations with well-developed kinematic indicators such as accretionary mineral steps (mostly calcite and quartz), and slickolites. The most reliable kinematic markers for shear sense determination are extensively discussed elsewhere (e.g., Petit, 1987; Lee, 1991; Doblas, 1998). Although most of fault planes show well-developed kinematic indicators, in some of the cases it is difficult to determine the fault pattern because of the lack of these indicators, and poor exposures. However, most fault-slip indicators show a dominant occurrence of strike-slip faults with both sinistral and dextral sense of movement. Normal and reverse faults are generally much less common. Deformation bands, with mostly sub-vertical to vertical planes, were measured from outcrops of the Cambrian sandstone at sites R8, R9 and P18 (Fig. 10a). They show the occurrence of two strike maxima, NW-SE and NNE-SSE (Fig. 10b). In addition, there is a smaller but still notable set of DBs' trends of $\sim \mathrm{NE}-\mathrm{SW}$. Dyke systems are present in Neoproterozoic rock (sites A1 to A9, Fig. 10a) with sub-vertical to vertical dipping planes. They display two major orientations at roughly NE$\mathrm{SE}$ and $\sim \mathrm{E}-\mathrm{W}$ with a secondary trend of NW-SE (Fig. 10b). In Fig. 10c-e, rose diagrams show the dominant direction of measured structural planes (faults, dykes and DBs) at each site separately. Most of the rose diagrams show an agreement in orientation azimuth along the NWSE direction. Overall, the structural features at the outcrop scale are oriented $\sim \mathrm{N}-\mathrm{S}$, NW-SE, NE-SW and $\sim \mathrm{E}-\mathrm{W}$. 

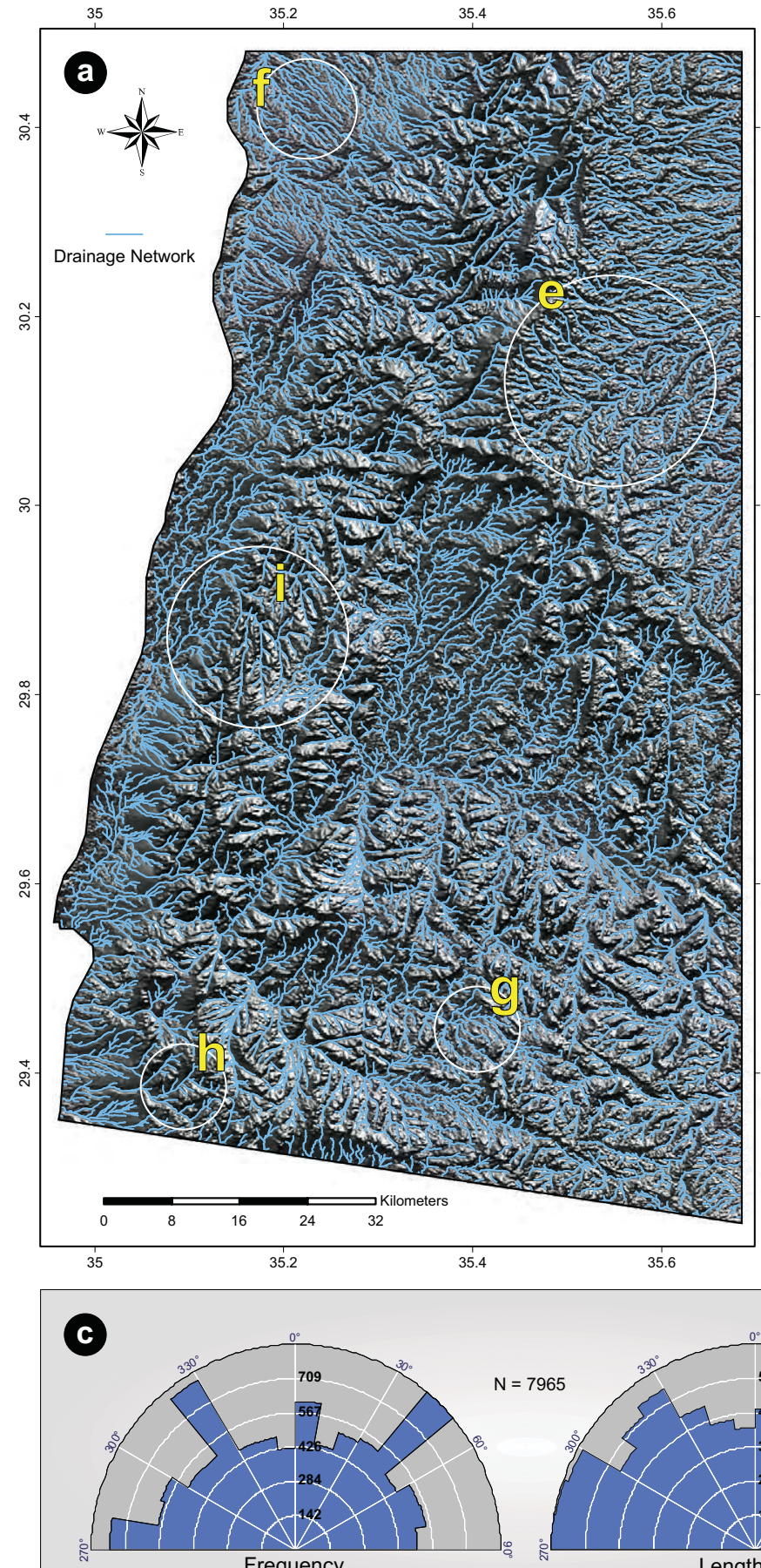

Frequency

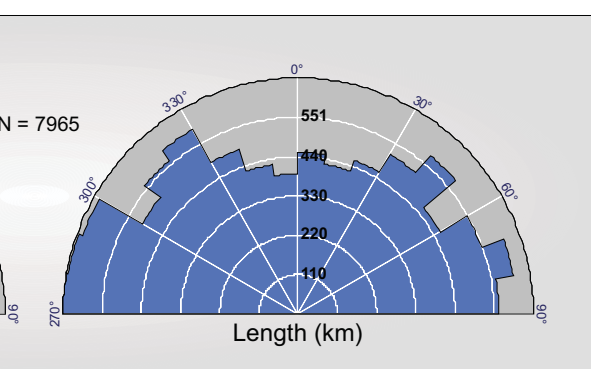

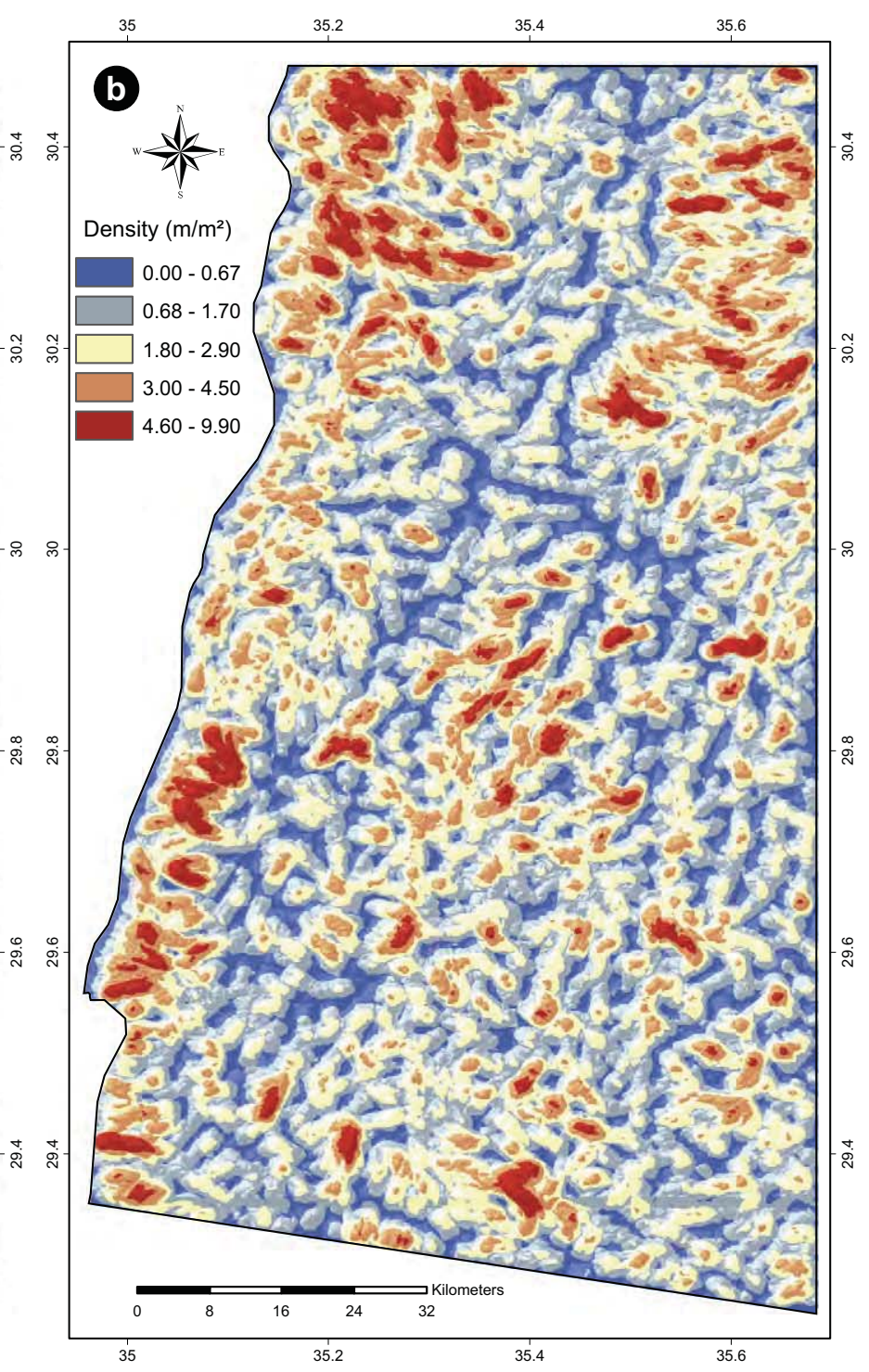

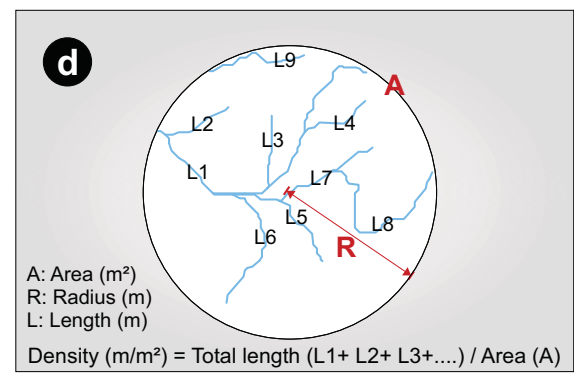

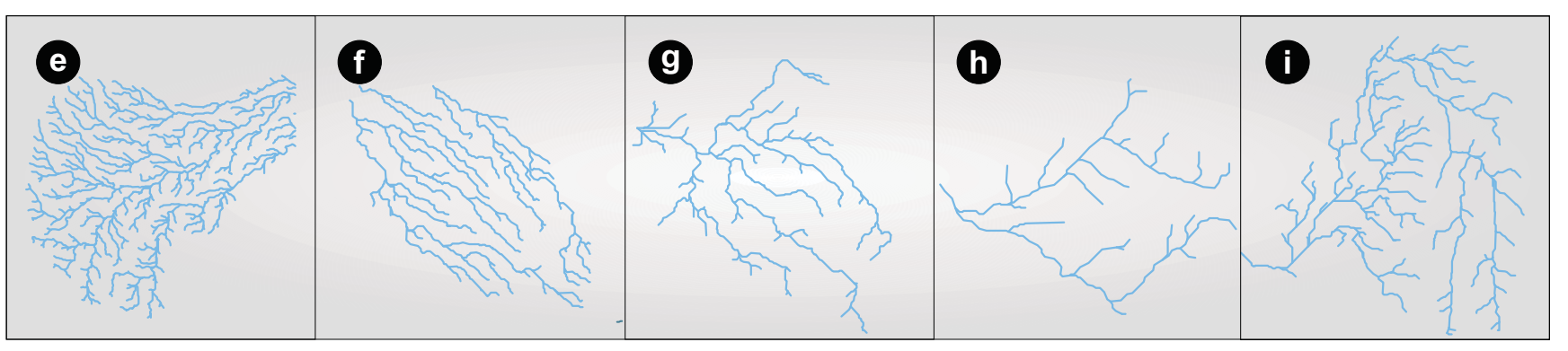


For comparative purposes, and to obtain further information, the measured structural data were summarized into three broad categories according to their spatial distribution: Petra, Ras-En Nagab, and Aqaba (Fig. 10f). A lower hemisphere equal-area contour plot of poles to planes and a rose diagram were prepared separately for each category. The contour diagrams were prepared using the method of Kamb (1959), in order to reveal the distribution of percentage values with respect to all measured data. In Ras en-Naqab, the contour plot of poles to the structural planes (faults and DBs) shows a distinctive number of NWSE and NE-SW trending sub-vertical planes; with a secondary cluster at roughly $\sim \mathrm{N}-\mathrm{S}$ and $\sim \mathrm{E}-\mathrm{W}$. The dominant NW-SE orientation noted here is commonly parallel to the main extensional structures affecting southern Jordan, and producing long and deep escarpment structures, e.g., Ras en-Naqab escarpment. These results more or less agree with those obtained from the Petra region. In the Aqaba region, the contour diagram of poles to all measured structural planes (faults and dykes) shows two distinct clusters of the sub-vertical planes, one roughly N$\mathrm{S}$ and the other roughly E-W, which are respectively parallel and perpendicular to the Dead Sea Fault zone.

\section{Discussion}

\subsection{Surface geomorphological features vs. subsurface structures}

Automated lineament mapping using remote sensing datasets succeed to capture several intersecting populations of lineaments with various lengths and orientations. The three main orientations are $\sim \mathrm{N}-\mathrm{S}$, $\sim \mathrm{E}-\mathrm{W}$, and NE-SW with a secondary orientation of NW-SE (Fig. 7c). The azimuth distributions of streams is similar to that of the lineaments (Fig. 9c), although there are a few differences in the prevailing directions. The lineaments have a secondary NW-SE trend which is a main trend in stream distributions. This similarity in azimuth directions indicates that the lineaments constitute preferred zones for surface water runoff, fluvial incision and probably downward water percolation during rainfall events. There are considerable differences in the spatial distribution of lineament and stream densities over the study area (Figs. 7b and $9 \mathrm{~b}$ ). High lineament density is generally related to high topographic relief rather than to drainage density. This is because most high areas that are not usually covered by a large amount of surficial deposits usually represent areas of complex structural deformation and commonly contain well-discernible fault, fracture, and dyke systems that are clearly visible on the ground surface.

A general similarity between the lineament trends of the studied area and the orientations of the subsurface structural features was observed. This relationship is noticeable at different outcrop sites along the study area, where there are four trends of structural elements along $\sim \mathrm{E}-\mathrm{W}, \sim \mathrm{N}-\mathrm{S}, \mathrm{NW}-\mathrm{SE}$ and NE-SW. The best agreement in the direction of lineaments derived from remotely sensing data and the measured structural features occurs in most outcrop localities within the Aqaba area ( sites A1, A2, A3, A4, A5, A7, and A8, Fig. 10e). Other outcrop localities that yielded a good agreement in the directional behaviour are R2, R3, P7, P8, P9, and P11 (Fig. 10c,d). Many outcrop localities, particularly in the Petra and Ras en-Naqab areas, have linear structural features that do not agree well with the extracted lineament trends. The reason is that the outcrop locality represents a very small exposure that does not allow recognition all the structural features. Based on similarities in the distribution of azimuth directions, the linear surface features of the study area can be correlated with the linear structural features (faults, dykes, DBs and other elements) most probably represent an upward continuation of subsurface buried structures. Thus, the development of present landform characteristics appears to be influenced by subsurface buried structures.

\subsection{Drainage patterns and anomalies}

In recent years, drainage patterns and anomalies have been the subject of many geological and geomorphological studies. The drainage pattern of a region records evidence of tectonic deformation (e.g., Howard, 1967; Schumm and Geophysics Study Committee, 1986; Jackson et al., 1998). Neotectonic activity significantly controls drainage patterns and creates anomalies in their spatial distribution (e.g., Seeber and Gornitz, 1983; Ouchi, 1985; Schumm and Geophysics Study Committee, 1986; Schumm et al., 2002). Specifically where they cross active faults, drainages show anomalous patterns and detectable changes in gradients along their courses (e.g., Seeber and Gornitz, 1983; Schumm and Geophysics Study Committee, 1986; Valdiya and Rajagopalan, 2000). Investigation of such drainage anomalies, which reflect deviation from common regional patterns, can thus provide valuable information on active tectonic deformation, and underlying geologic structures and rock type (Zernitz, 1932; Ray, 1960; Howard, 1967; Goldsworthy and Jackson, 2000; Twidale, 2004).

The drainage network of the study area is predominantly of a dendritic pattern, in particular in the northeastern area (Fig. 9e). This type of drainage pattern consists of channels oriented in a wide range of directions and forms in areas of flat-lying rocks with more or less uniform resistance to erosion (Ray, 1960; Clark et al., 2004; Twidale, 2004), and without significant structural or slope influence (Zernitz, 1932; Twidale, 2004). Parallel and sub-parallel drainage patterns are also common, especially in the northwestern part of the area (Fig. 9f), and form in areas where the surface water flow is highly controlled by slope gradient and lack of structural interference (Howard, 1967; Twidale, 2004). Trellis and rectangular patterns (Fig. 9g,h) are less common in this area than patterns mentioned above, and commonly reveal the influence of fault and joint systems (Ray, 1960; Clark et al., 2004). In some places, the drainage pattern is intermediate between dendritic and trellis (Fig. 9i). Trellis characteristics may appear within a dendritic pattern due to significant structural control, the lithologic character of the underlying rocks, or variations in subsidence and uplift patterns (Ray, 1960; Howard, 1967; Clark et al., 2004).

Gradient variations along stream long profiles also allows the identification of drainage anomalies (Hack, 1973; Seeber and Gornitz, 1983; Ouchi, 1985; Miller, 1991; Clark et al., 2004; Duvall et al., 2004; Larue, 2007; Shahzad et al., 2009). These anomalies are commonly referred to as knickzones or knickpoints. The latter are points of discontinuity or steep segments in a river profile that are usually a response to climate changes, stream power, lithological variability, or tectonic distortions (Hack, 1973; Seeber and Gornitz, 1983; Miller, 1991; Alexandrowicz, 1994; Zaprowski et al., 2001; Duvall et al., 2004; Bishop et al., 2005; Carretier et al., 2006; Hayakawa and Oguchi, 2006; Larue, 2007). The study of longitudinal profile anomalies can thus give information about lithological and/or tectonically influence on parts of the drainage system if other factors such as climate and stream power can be discarded. In the current study an attempt was made to identify knickpoints on longitudinal stream profiles and to assess whether they have a lithology and/or tectonic origin. Other factors affecting

Fig 9. Drainage network characteristics of the SW Jordan. (a) Surficial stream network of the study area derived from the ASTER-GDEM with a flow accumulation threshold of 500 cells. The drainage channel is indicated by a solid light blue line, superimposed on the flow direction map of the study area. (b) Drainage density map with a search radius of 1 km. (c) Frequency and length weighted-rose diagrams of all extracted stream channels indicating four main directions of preferential flow for the surficial water: $\sim$ E-W, NW-SE, NE-SW, and $\sim \mathrm{N}-\mathrm{S}$. (d) Illustration of drainage density analysis. Different drainage patterns were recognized in the study area, namely: (e) dendritic, (f) parallel and sub-parallel, ( $\mathrm{g}$ ) trellis, (h) rectangular, and (i) a transition between dendritic and trellis. The location of these patterns is indicated by circles with white border in (a). (For interpretation of the references to colour in this figure legend, the reader is referred to the web version of this article.) 

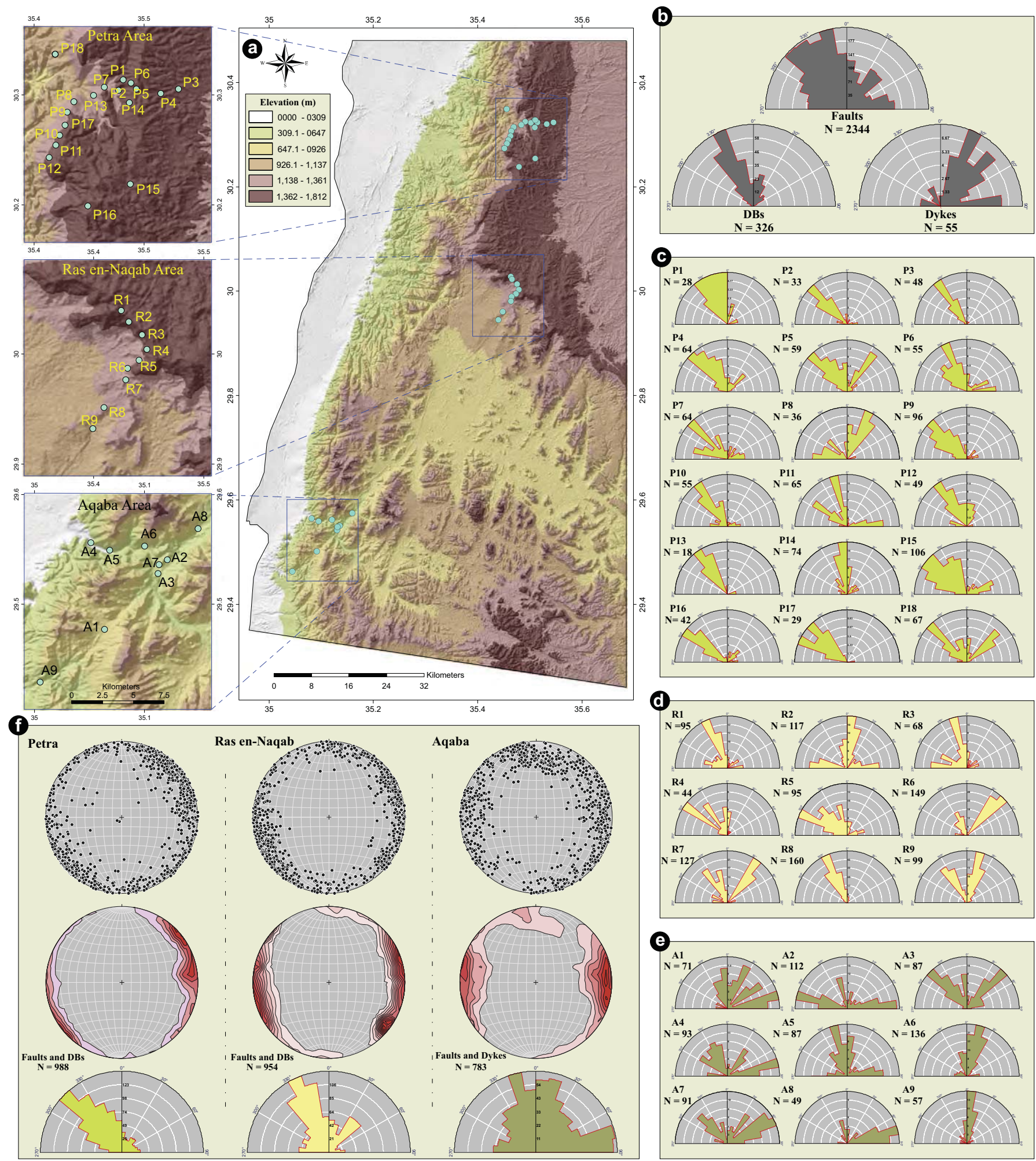

Fig. 10. Analysis of structural features. (a) A colour-coded elevation image showing spatial distribution of study sites in the southwestern part of Jordan. (b) Rose diagrams showing the dominant strikes of the different types of measured structural features, including faults, deformation bands (DBs), and dykes. (c)-(e) Rose diagrams showing the orientation frequency for the measured structural features at the outcrop scale. (f) Kamb contour diagrams of poles to planes (upper and middle diagrams) and rose diagrams summarize the orientations of the measured structural planes (faults, DBs, and dykes) depending on their local distribution, and are therefore subdivided into three groups: Petra (faults and DBs), Ras-En Nagab (faults and DBs), and Aqaba (faults and dykes). The Kamb contoured stereonets, lower hemisphere equal-area projections, were plotted using Stereonet 9 (Cardozo and Allmendinger, 2012). (For interpretation of the references to colour in this figure legend, the reader is referred to the web version of this article.)

stream gradient are not addressed in the present study. It is important to bear in mind that it may not always be possible to identify the exact causes of the knickpoint without much more detailed study.
Moreover, not all knickpoints are taken into account. Some small anomalies were not considered, since their size could be within the inaccuracy or unavailability of elevation data. 
Fig. 11 shows the longitudinal profiles of five large tributaries, labeled from $\mathrm{V}$ to $\mathrm{Z}$, that drain into the Wadi Araba rift valley. These profiles show variable curves and gradients. The longitudinal elevation curve of the stream V (Fig. 11a) is composed of two main parts (upper and lower) separated by a very sharp knickzone between $\mathrm{km} \sim 24$ and 26. Slope curve shows a very similar spatial pattern, through a significant change in the slope gradient into a single sharp peak with a very high slope value of $61.5^{\circ}$. The upland surface which is in the upstream portions above the main knickzone reflects a long-lived, slowly eroding relict landscape, whereas the lower portion reflects a relatively young and rapidly evolving landscape (e.g., Clark et al., 2005; Clark et al., 2006). The knickzone is a deep cut valley, and is characterized by a

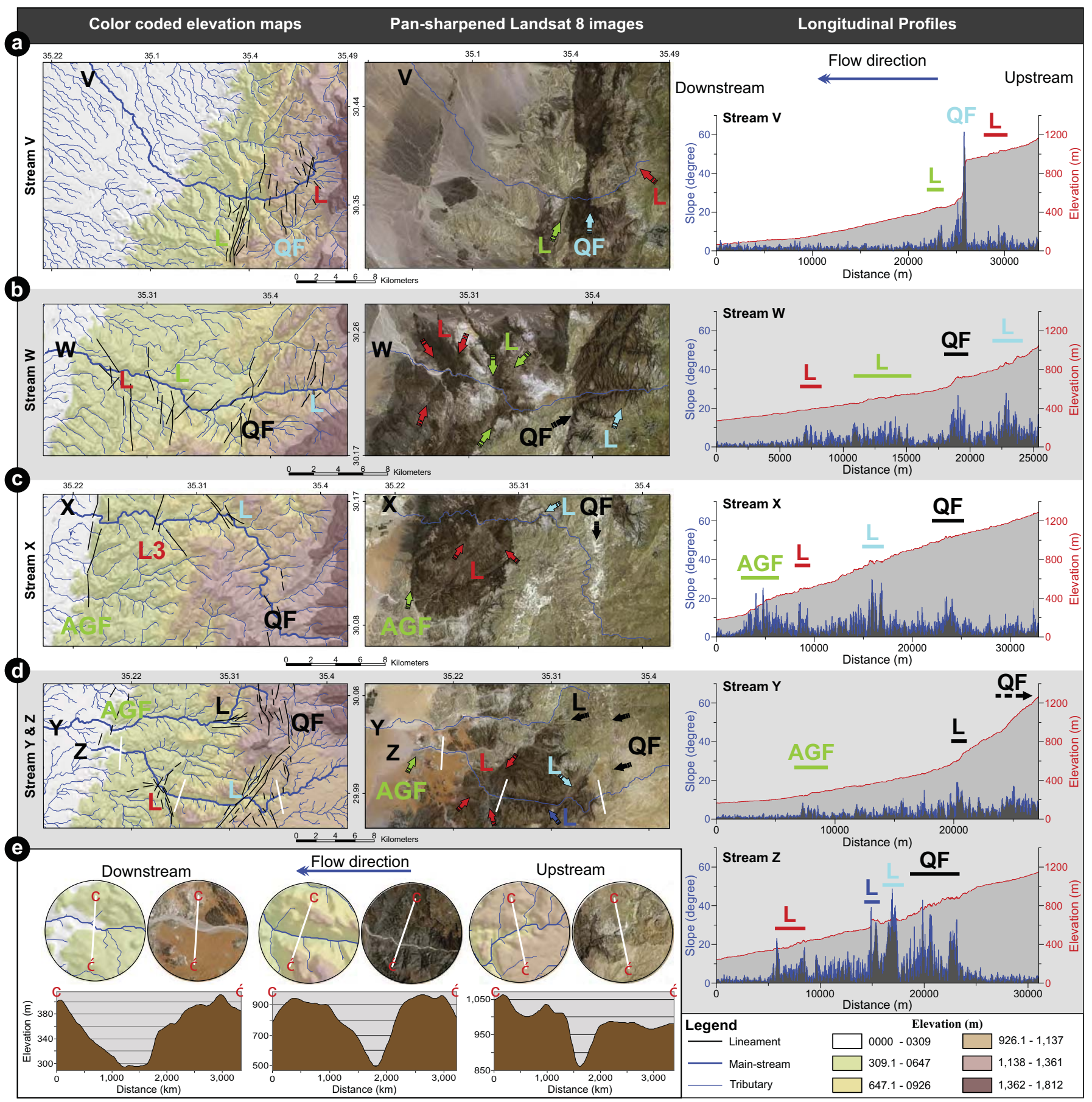

Fig. 11. Analysis of longitudinal and cross-sectional stream channel profiles in the SW Jordan. (a)-(d) Longitudinal profiles of five large tributaries draining into the Wadi Araba rift valley, southwest of Jordan. The location of these profiles is presented in Fig. S1 in the Supplementary online material. The longitudinal profile (third column) was generated from the $30 \mathrm{~m}$ ASTER-GDEM data. Red and blue curves in the profiles indicate, respectively, the variation of the elevation and slope as a function of distance along the stream route. Slope curves help to identify some of the more subtle breaks. AGF, Aqaba-Gharandal Fault; L, tectonic Lineament; QF, Quwayra Fault. All the streams have one or more knickpoints and they show deflection near the confluence with the faults and tectonic lineaments. (e) Cross profiles showing the variations in the channel dimensions at certain points in the stream $\mathrm{Z}$ course. The location of these profiles is indicated by thick white lines crossing the stream $\mathrm{Z}$ course. The stream shows a deeply incised V-shaped valley in the upper and middle courses, resulting from the large amount of vertical erosion and little lateral erosion. In the lower course the valley has relatively a wide and flat bottom but its depth has not changed significantly due to increased lateral erosion and decreased vertical erosion. (For interpretation of the references to colour in this figure legend, the reader is referred to the web version of this article.) 
$300 \mathrm{~m}$ high waterfall that cascades over ancient volcanic rocks of the Precambrian age. The presence of such hanging valleys reflects an abrupt increase in erosion rates along the stream and gives compelling evidence for tectonically-triggered disequilibrium conditions (Crosby et al., 2007; Kale et al., 2013). The change in the longitudinal profile is attributed to a prominent $\sim \mathrm{N}-\mathrm{S}$ trending tectonic lineament that aligns with the Quwayra Fault (QF), which is responsible for the abrupt spatial changes in lithology and topography of the area, as indicated on the pansharpen image. Farther downstream, the slope and elevation gradient becomes relatively gentle again, even though the entire profile is not perfectly smooth. In addition to the main knickpoint, there are two other anomalies in the upper and lower parts of the profile at $\mathrm{km} \sim 29$ and $\sim 23$, respectively. The upper one coincides with NW-SE trending tectonic lineaments (labeled with red L), whereas the lower one corresponds mainly with NNE-SSW trending tectonic lineaments (labeled with green $\mathrm{L}$ ).

Stream $\mathrm{W}$ is about $16 \mathrm{~km}$ south of stream V. Its profile shows more than three main knickpoints (Fig. 11b). Two of them are steeper steps in the profile developed on the upstream side between $\mathrm{km} 18$ and 24 (labeled with QF and cyan L), and coincide respectively with NNESSW trending tectonic lineaments (cyan L) and the QF. The central part of the channel shows a broad but gentle knickzone developed between $\mathrm{km} \sim 7$ and 15 (labeled with green and red $\mathrm{L}$ ). The stream is crossed by two sets of tectonic lineaments trending NW-SE to NESW, which could account for the presence of this knickzone. At the western end of the profile, the stream gradient becomes relatively smooth, because of the gently dipping surface of the Wadi Araba valley.

Stream X is about $24 \mathrm{~km}$ south of the stream V and shows broad, steep and extensive knickpoints along the whole length of its course (Fig. 11c). Across the QF, the stream shows an abrupt deflection toward the north with a prominent change in elevation and slope at $\mathrm{km} \sim 24$. This change does not correspond to any lithologic variation, as indicated from the geological map and the pansharpened image, and is thus considered to be a quick response to recent movement along the QF. Farther downstream, several knickpoints are also observed. One of them is a steeper step in the profile, developed at $\mathrm{km} \sim 16$, and coincides with NW-SE trending tectonic lineaments (cyan L). Farther west, toward the end of profile, there are two obvious knickpoints developed between $\mathrm{km} \sim 3$ to $\sim 10$. Both are very significant and coincide respectively with $\mathrm{N}-\mathrm{S}$ trending AGF and with multiple directions of tectonic lineaments, mostly of NW-SE to NE-SW, which could account for the presence of these anomalies.

Stream Y lies about $36 \mathrm{~km}$ south of the stream V and has intermediate to weak knickzones along its course (Fig. 11d). On the upstream side, the longitudinal profile shows a prominent change in gradient near the western side of the QF. A sudden change in stream gradient from steep to gentle is noted at $\mathrm{km} \sim 21$. This knickzone coincides with $\sim \mathrm{E}-\mathrm{W}$ trending tectonic lineaments, which could account for the sharp deflection in the direction of the stream from NNE-SSW to almost $\mathrm{E}-\mathrm{W}$. Farther west, in the downstream direction, a number of small knickpoints are observed. The most obvious one is developed at km $\sim 7.5$, which may be formed owing to the AGF. The latter is not clearly expressed at the surface because the huge accumulation of windblown sand.

Stream Z, close to the stream Y, reveals a broad, steep and extensive knickzone, developed in the central part of its course (Fig. 11d). Upstream and downstream sides approximate a smooth curve, without marked discontinuities. The longitudinal profile has a prominent change in gradient across the $\mathrm{QF}$, between $\mathrm{km} \sim 18$ and $\sim 24$. Farther downstream, several knickpoints are also present. Two of them are steeper steps in the profile, developed at $\mathrm{km} \sim 17$ and $\sim 15$, and coincide respectively with NE-SW trending deep and long straight valley (labeled with cyan L) and the NW-SE tectonic lineament (labeled with blue L). The other obvious and important anomaly, between $\mathrm{km} \sim 5$ and $\sim 9$, is associated with NW-SE to NE-SW trending tectonic lineaments (labeled with red $\mathrm{L}$ ), which could account for the presence of this anomaly.
One of the most important notes here is the persistency of drainage anomalies in all streams that cross the QF. The consistency and persistency of drainage anomalies, which can be observed along several profiles crossing the same fault, is highly significant and is helpful in the recognition of neotectonic activity (Audemard, 1999; Burrato et al., 2003; Hartvich, 2005; Ollarves et al., 2006; Maroukian et al., 2008; Štěpančíková. et al., 2008; Zárate et al., 2014). The occurrence of these anomalies across QF, which is a sinistral strike-slip fault, can be explained by the reactivation of the $\mathrm{QF}$ during recent tectonic phases. Any small movement on the QF induces slight changes in ground surface properties that are enough to cause the anomalies in the stream network, even though it does not have a discernible morphological expression. The cross-profiles (Fig. 11e) that cross stream Z at different locations reveal an abrupt change in its geomorphologic configuration, with a deeply incised V-shaped valley upstream changing into a wide valley with a flat bottom downstream. Analysing such valley cross-sectional shapes is helpful to explore the influence of tectonic forces on valley morphology (Prasicek et al., 2015). The changes in depth of the valley bottom generally imply changing erosion rates along the stream, possibly resulting from tectonic uplift or subsidence (Bonnet et al., 2000).

\subsection{Tectonic implications of the lineaments}

The most distinguishing characteristic of the southwestern part of Jordan is that it consists of different geological units and several prominent structures. Geological units with different ages can provide relative constraints on the ages of the lineaments that cross them. This depends upon the reliability or precision of geological maps. Geology of the study area was compiled from 17 1:500,000 scale maps covering the southwestern part of Jordan. Despite possible pitfalls, an attempt was made to detect changes in lineament orientations through geologic time. Lineaments were subsequently grouped according to age of host rocks. The lineaments of each geological age were individually analyzed using both frequency and length weighted rose diagrams. Five populations of lineaments were obtained: those observed in late Precambrian basement rocks, and those recognized in early Paleozoic, Mesozoic, Tertiary and Quaternary sedimentary rocks. Temporal evolution of the lineament trends in various geologic formations is shown in Fig. 12. The results show that the $\sim \mathrm{N}-\mathrm{S}$ trend continued from the Precambrian to Quaternary, but in the Tertiary it becomes less prominent (Fig. 12b). This could be because the Tertiary outcrops, which mainly crop out in the northeastern part of the area, are too small to detect significant linear features by remote sensing techniques. The E-W trend also affected all exposed rocks from Precambrian to Quaternary, but it is very conspicuous in Cretaceous, and Tertiary rocks. The NE-SW trend is well documented in the Precambrian, lower Paleozoic, Mesozoic and in the Quaternary formations, while the NW-SE trend is well represented in Quaternary units. Similarly, NE-SW trending lineaments are more abundant in the Precambrian of Egypt's Sinai Peninsula compared with NW-SE trends (Masoud and Koike, 2011a).

A noteworthy point is that Quaternary tectonic activity enhanced the NW-SE trend compared with those that preceded it. The evolution of this trend most probably represents the lineaments associated with continued collision between Arabian and Eurasian plates. Occurrence and relative abundance of three prominent trends $(\sim \mathrm{N}-\mathrm{S}, \mathrm{E}-\mathrm{W}$, and $\mathrm{NE}-\mathrm{SW}$ ) through geological time proposed to be generated by repeated reactivation of pre-existing crustal structures during various tectonic episodes.

The inherited fault planes of ancient tectonic deformations can easily be reactivated if they are either favorably or unfavorably oriented relative to the subsequent stress regimes (Bartholomew et al., 2002). Late Cenozoic tectonic activity of the southwestern part of Jordan was dominated mainly by compressional/strike-slip stress regimes that caused widespread reactivation of inherited crustal structures and established new ones (Radaideh and Melichar, 2015). 

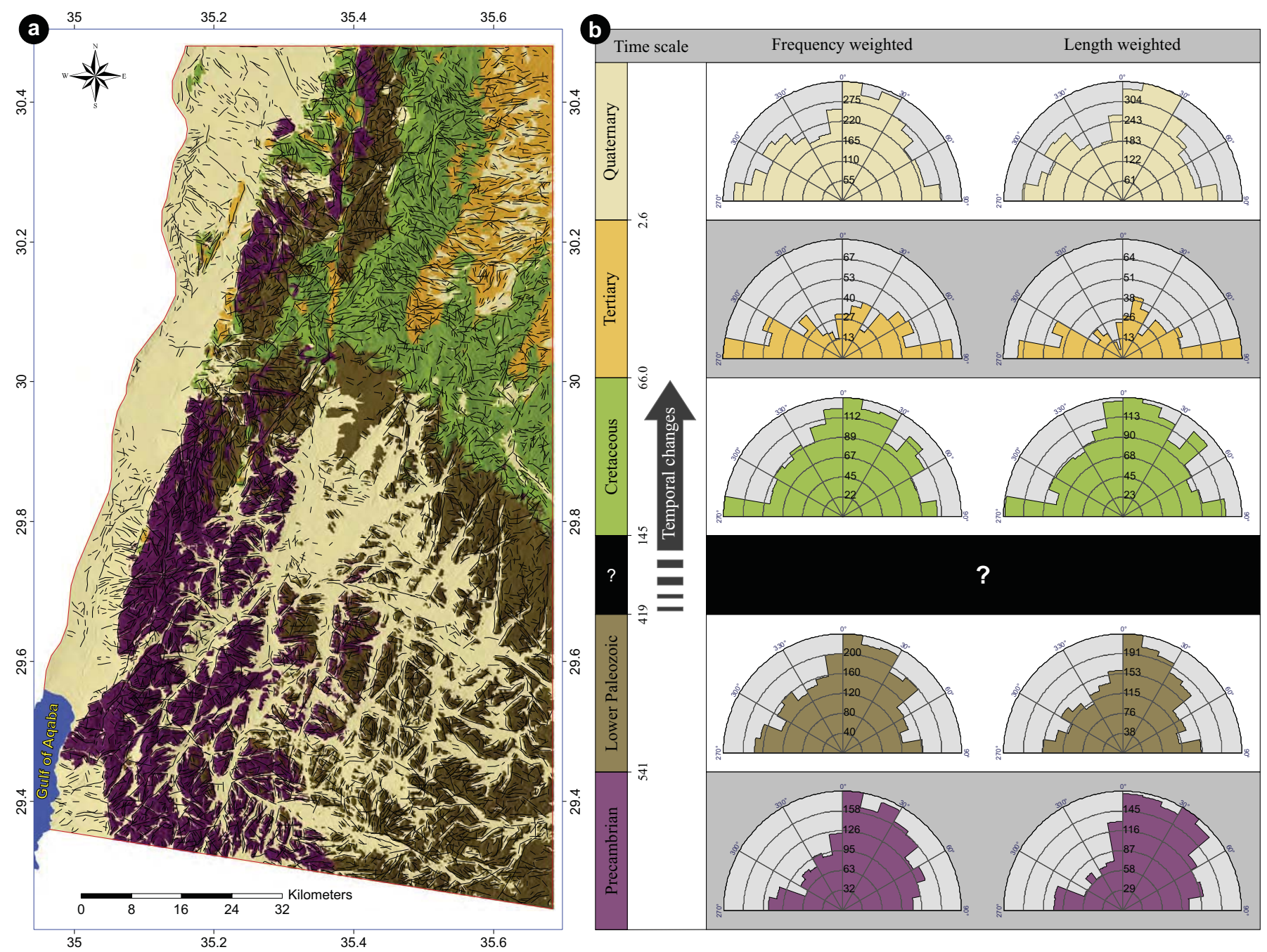

Fig. 12. Temporal evolution of the lineament trends in the SW Jordan. (a) Spatial distribution of lineaments through the main geologic units. (b) Frequency and length weighted-rose diagrams depicting the strike directions of the detected lineaments over the main exposed rocks of the area. The numerical time scale is from Walker et al. (2012). (For interpretation of the references to colour in this figure legend, the reader is referred to the web version of this article.)

Correspondingly, present-day stress field can repeatedly reactivate the pre-existing faults and control their upward propagation into younger strata. The region's current stress field is characterized by a compressive maximum horizontal stress (SHmax) with NW-SE direction (Hurd, 2010). As a first order approximation, the spatial pattern of lineaments can be interpreted by a sinistral simple shear tectonic model (Woodcock and Schubert, 1994). Considering a major fault striking $\mathrm{N} 16^{\circ} \mathrm{E}$, parallel to the strike of the WAF; the dominant system of $\sim \mathrm{N}-\mathrm{S}$ trending lineaments can be interpreted as synthetic sinistral R-shear fractures (Fig. 13); the NW-SE trending lineaments can be interpreted as antithetic dextral R'-shear fractures; and the $\sim \mathrm{E}-\mathrm{W}$ and NE-SW trending lineaments as secondary antithetic X-and synthetic P-shear fractures respectively. The dominant strike-slip faults of both sinistral and dextral senses with different trends in the study area may support this kinematic model.

\section{Conclusions}

This paper shows the results of a combined use of remote sensing and GIS analysis techniques in an attempt to interpret the complex and complicated patterns of the landscape features of the late Precambrian to Quaternary age in the SW Jordan. Hill-shaded images derived from $30 \mathrm{~m}$ resolution DEM data and Landsat 8 bands with different spatial resolutions were used to automatically extract linear features and analyse their tectonic significance in the study area. The application of multi-illuminated hill-shading procedures allowed us to resolve impediments in the determination of linear surface features, which would be unresolvable if only one lighted hill-shaded image was used. Ground-based structural field datasets for verifying the findings of the remote sensing analysis was performed. The response of streams to the lineaments and active faults is clearly observed in the form of sudden dramatic changes in the gradients and patterns of streams. The drainage patterns include dendritic, parallel, rectangular, trellis, and modified dendritic/trellis. Four sets of lineaments are affected the SW Jordan trending $\sim \mathrm{E}-\mathrm{W}, \sim \mathrm{N}-\mathrm{S}, \mathrm{NE}-\mathrm{SW}$, and NW-SE. The latter is probably the youngest lineaments in the study area. Other trends are probably related to repeated reactivation of pre-existing crustal structures during various tectonic episodes. A general similarity between the lineament trends and the orientations of both drainage system segments and subsurface structural features suggests that development of present landform characteristics is highly controlled or influenced by subsurface buried structures. The evolution of these lineaments is attributed to the reactivation of pre-existing faults and deep inherited discontinuities under the present-day stress field.

Supplementary data to this article can be found online at http://dx. doi.org/10.1016/j.geomorph.2016.09.033. 

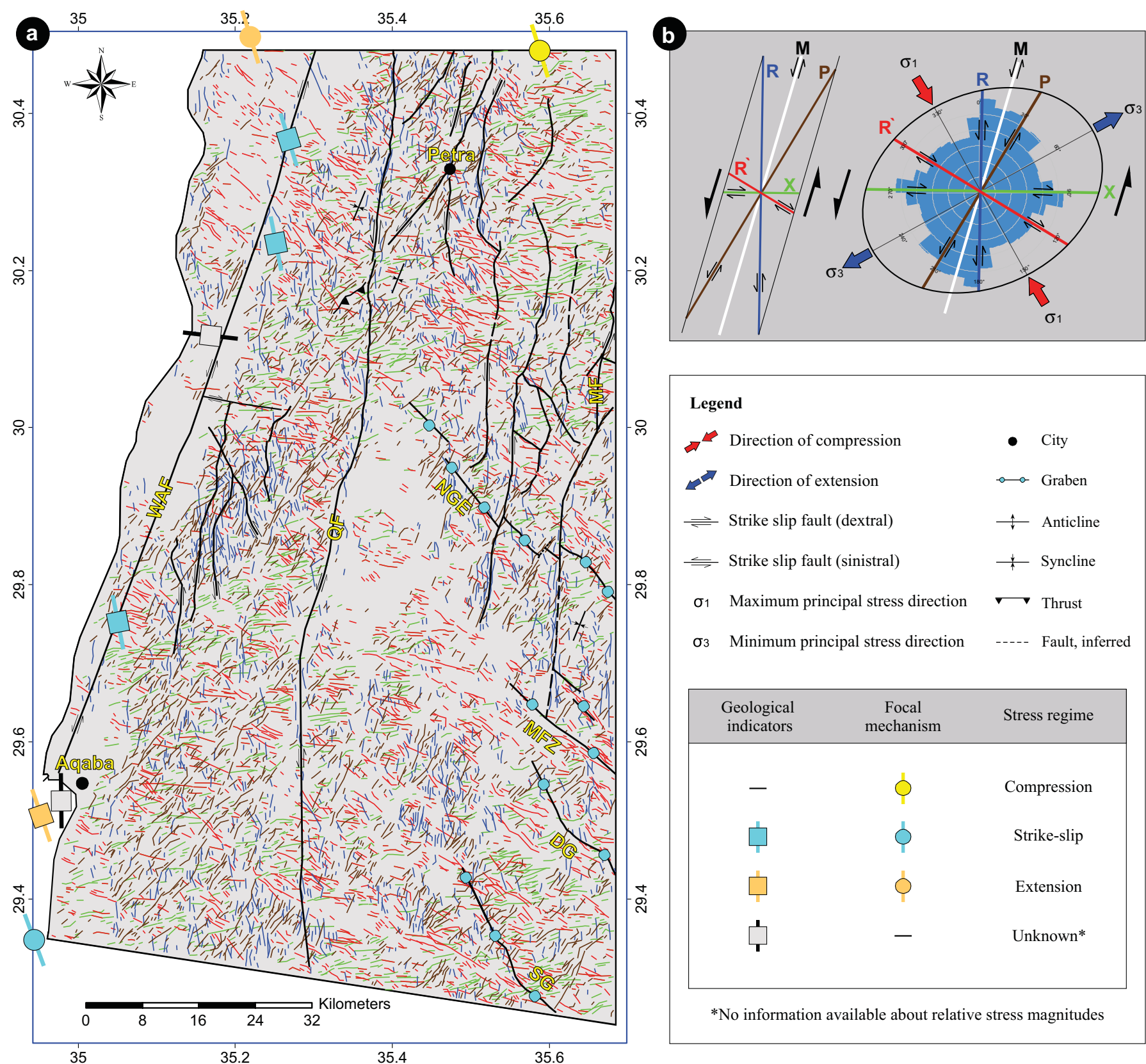

\begin{tabular}{|c|c|c|}
\hline $\begin{array}{c}\text { Geological } \\
\text { indicators }\end{array}$ & $\begin{array}{c}\text { Focal } \\
\text { mechanism }\end{array}$ & Stress regime \\
\hline \multirow[t]{4}{*}{-} & & Compression \\
\hline & & Strike-slip \\
\hline & C & Extension \\
\hline & - & Unknown* \\
\hline
\end{tabular}

*No information available about relative stress magnitudes

Fig. 13. Tectonic implications of lineament directions in the SW Jordan. (a) Interpretation of the derived lineaments according to strain ellipse and simple shear mechanism model in (b). The model (adopted from Woodcock and Schubert, 1994) has linked to a present-day stress tensor characterized by a principal compressive axis striking NW-SE (150 ${ }^{\circ}$ ), leading to a sinistral movement along the Wadi Araba Fault (WAF). M, Master fault, parallel to the strike of the WAF; P, secondary synthetic shears; R, synthetic Riedel shears; R', antithetic Riedel shears; X, secondary antithetic Riedel shears. Other abbreviations are the same as in Fig. 2.

\section{References}

Abarca, M.A.A., 2006. Lineament Extraction From Digital Terrain Models. Case Study San Antonio del Sur Area, South- Eastern Cuba (MSc Thesis) Faculty of Geoinformation Science and Earth observation (ITC), University of Twente, Enschede, Netherlands.

Abdallah, C., 2010. Spatial distribution of block falls using volumetric GIS-decision-tree models. Int. J. Appl. Earth Obs. Geoinf. 12 (5), 393-403. http://dx.doi.org/10.1016/j. jag.2010.05.008

Abdullah, A., Akhir, J.M., Abdullah, I., 2009. A comparison of landsat TM and SPOT data for lineament mapping in Hulu Lepar area, Pahang, Malaysia. Eur. J. Sci. Res. 34 (3), 406-415.

Abdullah, A Akhir, J.M., Abdullah, I., 2010. Automatic mapping of lineaments using shaded relief images derived from digital elevation model (DEMs) in the Maran - Sungi Lembing area, Malaysia. Electron. J. Geotech. Eng. 15 (J), 949-957.

Al Rawashdeh, S.A., Saleh, B., Hamzah, M., 2006. The use of remote sensing technology in geological investigation and mineral detection in El Azraq-Jordan. CyberGeo 12 (11), 1-22. http://dx.doi.org/10.4000/cybergeo.2856.

Alavi, M., 1991. Tectonic Map of the Middle East, Scale 1:5,000,000. Geological Survey of Iran, Tehran.

Alexandrowicz, Z., 1994. Geologically controlled waterfall types in the outer Carpathians. Geomorphology 9 (2), 155-165. http://dx.doi.org/10.1016/0169-555X(94)90073-6.

Ali, M., 2012. Identifying Neotectonic Features Using Lineament Analysis of Satellite Images in Tectonically Active Muzaffarabad Area, Azad Jammu \& Kashmir (M.Sc. Thesis) National Centre of Excellence in Geology (NCEG), University of Peshawar, Peshawar, Pakistan.

Amireh, B.S., Schneider, W Abed, A.M 1994. Evolving fluvial-transitional-marine deposition through the Cambrian sequence of Jordan. Sediment. Geol. 89 (1-2), 65-90. http://dx.doi.org/10.1016/0037-0738(94)90084-1.

Argyriou, A., 2012. A Methodology for the Rapid Identification of Neotectonic Features Using Geographical Information Systems and Remote Sensing: A Case Study From Western Crete, Greece (PhD Thesis) School of Earth and Environmental Sciences, University of Portsmouth, Portsmouth, United Kingdom.

Ariza-Villaverde, A.B., Jiménez-Hornero, F.J., Gutiérrez de Ravé, E., 2015. Influence of DEM resolution on drainage network extraction: a multifractal analysis. Geomorphology 241, 243-254. http://dx.doi.org/10.1016/j.geomorph.2015.03.040.

Arrowsmith, J.R., Zielke, O., 2009. Tectonic geomorphology of the San Andreas fault zone from high resolution topography: an example from the Cholame segment. Geomorphology 113 (1-2), 70-81. http://dx.doi.org/10.1016/j.geomorph.2009.01.002. 
Aubry, T., Luís, L., Dimuccio, L.A., 2011. Nature vs. culture: present-day spatial distribution and preservation of open-air rock art in the Côa and Douro River Valleys (Portugal). J. Archaeol. Sci. 39 (4), 848-866. http://dx.doi.org/10.1016/j.jas.2011.10.011.

Audemard, M.F.A., 1999. Morpho-structural expression of active thrust fault systems in the humid tropical foothills of Colombia and Venezuela. Z. Geomorphol. 118, 227-244.

Azizian, A., Shokoohi, A., 2014. DEM resolution and stream delineation threshold effects on the results of geomorphologic-based rainfall runoff models. Turk. J. Eng. Environ. Sci. 38 (1), 64-78. http://dx.doi.org/10.3906/muh-1401-13.

Bahrami, S., 2013. Analyzing the drainage system anomaly of Zagros basins: implications for active tectonics. Tectonophysics 608, 914-928. http://dx.doi.org/10.1016/j.tecto. 2013.07.026.

Bandel, K., Khoury, H., 1981. Lithostratigraphy of the Triassic in Jordan. Facies 4 (1), 1-26. http://dx.doi.org/10.1007/BF02536584.

Bartholomew, M.J., Stickney, M.C., Wilde, E.M., Dundas, R.G., 2002. Late Quaternary paleoseismites: syndepositional features and section restoration used to indicate paleoseismicity and stress-field orientations during faulting along the main Lima Reservoir fault, southwestern Montana. In: Ettensohn, F.R., Rast, N., Brett, C.E. (Eds.), Ancient Seismites. Geological Society of America, Boulder, Colorado, pp. 29-47 (Special Paper 359).

Batson, R.M., Edwards, E., Eliason, E.M., 1975. Computer-generated shaded-relief images. J. Res. U.S. Geol. Surv. 3 (4), 401-408.

Becker, J.J., et al., 2009. Global bathymetry and elevation data at 30 arc seconds resolution: SRTM30_PLUS. Mar. Geod. 32 (4), 355-371. http://dx.doi.org/10.1080/ 01490410903297766.

Beicip, 1981. Structural Map of Jordan, Scale 1:5,000,000. Geological Mapping Division, Natural Resources Authority, Amman, Jordan.

Ben-Avraham, Z., 1989. Multiple opening and closing of the eastern Mediterranean and South China basins. Tectonics 8 (2), 351-362. http://dx.doi.org/10.1029/ TC008i002p00351.

Bender, F., 1975. Geology of the Arabian Peninsula: Jordan. U.S. Geological Survey Professional Paper, 560-I. U.S. Government Publishing Office, Washington.

Beyer, H.L., 2004. Hawth's Analysis Tools for ArcGIS. Available online at http://www. spatialecology.com/htools/tooldesc.php (accessed 20/11/2015).

Bishop, P., Hoey, T.B., Jansen, J.D., Artza, I.L., 2005. Knickpoint recession rate and catchment area: the case of uplifted rivers in Eastern Scotland. Earth Surf. Process. Landf. 30 (6), 767-778. http://dx.doi.org/10.1002/esp.1191.

Bishta, A.Z., 2009. Lithologic discrimination using selective image processing technique of Landsat 7 Data, Um Bogma Environs Westcentral Sinai, Egypt. J. King Abdul Aziz Univ.: Earth Sci. 20 (1), 193-213. http://dx.doi.org/10.4197/Ear.20-1.10.

Bishta, A.Z., Sonbul, A.R., Qudsi, I.Z., 2014. Utilizing the image processing techniques in mapping the geology of Al Taif area, central eastern Arabian shield, Saudi Arabia. Arab. J. Geosci. 8 (6), 4161-4175. http://dx.doi.org/10.1007/s12517-014-1484-x.

Bonnet, S., Guillocheau, F., Brun, J.P., Van Den Driessche, J., 2000. Large-scale relief development related to quaternary tectonic uplift of a Proterozoic-Paleozoic basement: the Armorican massif, NW France. J. Geophys. Res. 105 (B8), 19273-19288. http://dx.doi. org/10.1029/2000JB900142.

Burdon, D.J., 1959. Handbook of the Geology of Jordan. Government of the Hashemite Kingdom of Jordan, Amman.

Burrato, P., Ciucci, F., Valensise, G., 2003. An inventory of river anomalies in the Po plain, northern Italy: evidence for active blind thrust faulting. Ann. Geophys. 46 (5), 865-882. http://dx.doi.org/10.4401/ag-3459.

Cardozo, N., Allmendinger, R.W., 2012. Spherical projections with OSXStereonet. Comput. Geosci. 51 (2013), 193-205. http://dx.doi.org/10.1016/j.cageo.2012.07.021.

Carretier, S., Nivie're, B., Giamboni, M., Winter, T., 2006. Do river profiles record alongstream variations of low uplift rate? J. Geophys. Res. 111 (F2), F02024. http://dx. doi.org/10.1029/2005JF000419.

Chaubey, I., Cotter, A.S., Costello, T.A., Soerens, T.S., 2005. Effect of DEM data resolution on SWAT output uncertainty. Hydrol. Process. 19 (3), 621-628. http://dx.doi.org/10. 1002/hyp.5607

Clark, M.K., Schoenbohm, L.M., Royden, L.H., Whipple, K.X., Burchfiel, B.C., Zhang, X., Tang, W., Wang, E., Chen, L., 2004. Surface uplift, tectonics, and erosion of eastern Tibet from large-scale drainage patterns. Tectonics 23 (1), TC1006. http://dx.doi.org/10. 1029/2002TC001402.

Clark, M.K., Maheo, G., Saleeby, J., Farley, K.A., 2005. The non-equilibrium landscape of the southern Sierra Nevada, California. GSA Today 15 (9), 4-10 (doi:10:1130/10525173(2005)015<4:TNELOT $>2.0$. CO;2).

Clark, M.K., Royden, L.H., Whipple, K.X., Burchfiel, B.C., Zhang, X., Tang, W., 2006. Use of a regional, relict landscape to measure vertical deformation of the eastern Tibetan Plateau. J. Geophys. Res. 111 (F3), F03002. http://dx.doi.org/10.1029/2005JF000294.

Cooper, G.R.J., 2003. Feature detection using sun shading. Comput. Geosci. 29 (8), 941-948. http://dx.doi.org/10.1016/S0098-3004(03)00091-8.

Cotter, A.S., Chaubey, I., Costello, T.A., Soerens, T.S., Nelson, M.A., 2003. Water quality model output uncertainty as affected by spatial resolution of input data. J. Am. Water Resour. Assoc. 39 (4), 977-986. http://dx.doi.org/10.1111/j.1752-1688.2003. tb04420.x.

Crosby, B.T., Whipple, K.X., Gasparini, N.M., Wobus, C.W., 2007. Formation of fluvial hanging valleys: theory and simulation. J. Geophys. Res. 112 (F3), F03S10. http://dx.doi. org/10.1029/2006JF000566.

Davison, I., Tatnell, M.R., Owen, L.A., Jenkins, G., Baker, J., 1998. Tectonic Geomorphology and Rates of Crustal Processes along the Red Sea Margin, north-West Yemen. In: Purser, B.H., Bosence, D.W.J. (Eds.), Sedimentation and Tectonics in Rift Basins: Red Sea-Gulf of Aden. Chapman and Hall, London, pp. 595-612.

Deffontaines, B., Lacombe, O., Angelier, J., Chu, H.T., Mouthereau, F., Lee, C.T., Deramond, J., Lee, J.F., Yu, M.S., Liew, P.M., 1997. Quaternary transfer faulting in the Taiwan foothills: evidence from a multisource approach. Tectonophysics 274 (1-3), 61-82. http://dx.doi.org/10.1016/S0040-1951(96)00298-3.
Development Team, G.R.A.S.S., 2015. Geographic Resources Analysis Support System (GRASS), an Open Source Geographic Information System (GIS) Software. Available online at https://grass.osgeo.org (accessed 13/09/2015).

Dilek, Y., 2009. Eastern Mediterranean geodynamics. Int. Geol. Rev. 52 (2-3), 111-116 http://dx.doi.org/10.1080/00206810902951031 (2010).

Doblas, M., 1998. Slickenside kinematic indicators. Tectonophysics 295 (1-2), 187-197. http://dx.doi.org/10.1016/S0040-1951(98)00120-6.

Duvall, A., Kirby, E., Burbank, D., 2004. Tectonic and lithologic controls on bedrock channel profiles and processes in coastal California. J. Geophys. Res. 109 (F3). http://dx.doi. org/10.1029/2003JF000086.

Duyverman, HJ. Harris, N.B.W. Hawkesworth, CJ. 1982. Crustal accretion in the pan-Africa: $\mathrm{Nd}$ and $\mathrm{Sr}$ isotope evidence from the Arabian shield. Earth Planet. Sci. Lett. 59 (2), 315-326. http://dx.doi.org/10.1016/0012-821X(82)90134-0.

Eppelbaum, L., Katz, Y., 2011. Tectonic-geophysical mapping of Israel and the eastern Mediterranean: implications for hydrocarbon prospecting. Positioning 2 (1), 36-54. http://dx.doi.org/10.4236/pos.2011.21004.

ESRI, 2011. Arc Hydro Geoprocessing Tools v. 2.0 - Tutorial. Environmental Systems Research Institute, Redlands, California, United States (251 p.).

ESRI, 2014. Arc Hydro Tools - Overview Document \#1. Environmental Systems Research Institute, Redlands, California, United States (26 pp.).

Fox, J.E., Ahlbrandt, T.S., 2002. Petroleum Geology and Total Petroleum Systems of the Widyan Basin and Interior Platform of Saudi Arabia and Iraq. U.S. Geological Survey Bulletin 2202-E. U.S. Department of the Interior, Denver, Colorado.

Fritz, H., Abdelsalam, M., Ali, K.A., Bingen, B., Collins, A.S., Fowler, A.R., Ghebreab, W. Hauzenberger, C.A., Johnson, P.R., Kusky, T.M., Macey, P., Muhongo, S., Stern, R.J., Viola, G., 2013. Orogeny style in the east African Orogen: a review of the Neoproterozoic to Cambrian tectonic evolution. J. Afr. Earth Sci. 86, 65-106. http:// dx.doi.org/10.1016/j.jafrearsci.2013.06.004.

Gabrielsen, R.H., Braathen, A., Dehls, J., Roberts, D., 2002. Tectonic lineaments of Norway. Nor. J. Geol. 82, 153-174.

Galli, P., 1999. Active tectonics along the Wadi Araba-Jordan Valley transform fault. J. Geophys. Res. 104 (B2), 2777-2796. http://dx.doi.org/10.1029/1998JB900013.

Garbrecht, J., Martz, L., 1994. Grid size dependency of parameters extracted from digital elevation models. Comput. Geosci. 20 (1), 85-87. http://dx.doi.org/10.1016/00983004(94)90098-1.

García, M.J.L., Camarasa, A.M., 1999. Use of geomorphological units to improve drainage network extraction from a DEM: comparison between automated extraction and photointerpretation methods in the Carraixet catchment (Valencia, Spain). Int. J. Appl. Earth Obs. Geoinf. 1 (3-4), 187-195. http://dx.doi.org/10.1016/S03032434(99)85012-0.

Gardosh, M., Druckman, Y., Buchbinder, B., Rybakov, M., 2008. The Levant Basin offshore Israel: stratigraphy, structure, tectonic evolution and implications for hydrocarbon exploration. Geological Survey of Israel Report GSI/4/2008, Israel, revised edition.

Garfunkel, Z., 1981. Internal structure of the Dead Sea leaky transform (rift) in relation to plate kinematics. Tectonophysics 80 (1-4), 81-108. http://dx.doi.org/10.1016/0040 1951(81)90143-8.

Garfunkel, Z., 1998. Constrains on the origin and history of the eastern Mediterranean basin. Tectonophysics 298 (1-3), 5-35. http://dx.doi.org/10.1016/S00401951(98)00176-0.

Geomatics, P.C.I., 2015. Geomatica Online Help. Available only at http://www. pcigeomatics.com/geomatica-help/ (accessed 08/01/2016).

Goldsworthy, M., Jackson, J., 2000. Active normal fault evolution in Greece revealed by geomorphology and drainage patterns. J. Geol. Soc. 157 (5), 967-981. http://dx.doi. org/10.1144/jgs.157.5.967.

Gürbüz, E., Kazancı, N., Gürbüz, A., 2015. Strike-slip faulting, topographic growth and block movements as deduced from drainage anomalies: the Yeşilımak River basin, northern Turkey. Geomorphology 246, 634-648. http://dx.doi.org/10.1016/j. geomorph.2015.07.018.

Hack, J.T., 1973. Stream-profiles analysis and stream-gradient index. J. Res. U. S. Geol. Surv. 1 (4), 421-429.

Hartvich, F., 2005. Analysis of the longitudinal profiles of selected rivers in the Šumava Mts., Southwest Bohemia. Miscellanea Geographica 11, 13-30.

Hayakawa, YS., Oguchi, T, 2006. DEM-based identification of fluvial knickzones and its application to Japanese mountain rivers. Geomorphology 78 (1-2), 90-106. http:// dx.doi.org/10.1016/j.geomorph.2006.01.018.

Holbrook, J., Schumm, S.A., 1999. Geomorphic and sedimentary response of rivers to tectonic deformation: a brief review and critique of a tool for recognizing subtle epeirogenic deformation in modern and ancient settings. Tectonophysics 305 (1-3) 287-306. http://dx.doi.org/10.1016/S0040-1951(99)00011-6.

Homberg, C., Bachmann, M., 2010. Evolution of the Levant margin and western Arabian Platform since the Mesozoic: introduction. In: Homberg, C., Bachmann, M. (Eds.), Evolution of the Levant Margin and Western Arabia Platform Since the Mesozoic. Geological Society, London, pp. 1-8 (Special Publications 341).

Horn, B.K.P., 1981. Hill-shading and the reflectance map. Proc. IEEE 69 (1), 14-47. http:// dx.doi.org/10.1109/PROC.1981.11918

Hosseinzadeh, S.R., 2011. Drainage network analysis, comparison of digital elevation model (DEM) from ASTER with high resolution satellite image and aerial photographs. Int. J. Environ. Sci. Dev. 2 (3), 194-198. http://dx.doi.org/10.7763/IJESD. 2011.V2.123.

Howard, A.D., 1967. Drainage analysis in geologic interpretation: a summation. Am. Assoc. Pet. Geol. Bull. 51 (11), 2246-2259.

Hubbard, B.E. Mack, TJ. Thompson, A.L, 2012. Lineament analysis of mineral areas of interest in Afghanistan. U.S. Geological Survey Open-File Report 2012-1048. U.S. Department of the Interior, Reston, Virginia.

Hung, L.Q., Batelaan, O., De Smedt, F., 2005. Lineament extraction and analysis, comparison of Landsat ETM and ASTER imagery: case study-Suoimuoi tropical karst 
catchment, Vietnam. Conference Proceedings of SPIE Vol. 5983. the International Society for Optical Engineering, Bruges, Belgium, pp. 1-12 http://dx.doi.org/10.1117/12 627699.

Hurd, O., 2010. World stress map of 2008 updated. CEUS SSC Project GIS Data Summary Available online at http://www.ceus-ssc.com (accessed 22/12/2015).

Ibrahim, K.M., McCourt, W.J., 1995. Neoproterozoic granitic magmatism and tectonic evolution of the northern Arabian shield: evidence from southwest Jordan. J. Afr. Earth Sci. 20 (2), 103-118. http://dx.doi.org/10.1016/0899-5362(95)00037-T.

Ibrahim, U., Mutua, F., 2014. Lineament extraction using landsat 8 (OLI) in Gedo, Somalia. Int. J. Sci. Res. 3 (9), 291-296.

Jackson, J., Van Dissen, R., Berryman, K., 1998. Tilting of active folds and faults in the Manawatu region, New Zealand: evidence from surface drainage patterns, New Zealand. J. Geol. Geophys. 41 (4), 377-385. http://dx.doi.org/10.1080/00288306. 1998.9514817.

Jarrar, G., Stern, R.J., Saffarini, G., Al-Zubi, H., 2003. Late- and post-orogenic Neoproterozoic intrusions of Jordan: implications for crustal growth in the northernmost segment of the east African Orogen. Precambrian Res. 123 (2-4), 295-319. http://dx.doi.org/10. 1016/S0301-9268(03)00073-1.

Jenness, J., 2013. DEM Surface Tools for ArcGIS Manual. Jenness Enterprises Available at http://www.jennessent.com/arcgis/surface_area.htm/ accessed 15/01/2016).

Jordan, G., Schott, B., 2004. Application of wavelet analysis to the study of spatial pattern of morphotectonic lineaments in digital terrain models. A case study. Remote Sens. Environ. 94 (1), 31-38. http://dx.doi.org/10.1016/j.rse.2004.08.013 (2005).

Kale, V.S., Sengupta, S., Achyuthan, H., Jaiswal, M.K., 2013. Tectonic controls upon Kaveri River drainage, cratonic Peninsular India: inferences from longitudinal profiles, morphotectonic indices, hanging valleys and fluvial records. Geomorphology 227 (2014), 153-165. http://dx.doi.org/10.1016/j.geomorph.2013.07.027.

Kamb, W.B., 1959. Ice petrofabric observations from Blue Glacier, Washington, in relation to theory and experiment. J. Geophys. Res. 64 (11), 1891-1909. http://dx.doi.org/10. 1029/JZ064i011p01891.

Kolodner, K., Avigad, D., McWilliams, M., Wooden, J.L., Weissbrod, T., Feinsten, S., 2006 Provenance of north Gondwana Cambrian-Ordovician sandstone: U-Pb SHRIMP dating of detrital zircons from Israel and Jordan. Geol. Mag. 143 (3), 367-391. http://dx doi.org/10.1017/S0016756805001640.

Kröner, A., Stern, R.J., 2004. AFRICA|pan-African orogeny. Encycl. Geol. 1, 1-12. http://dx. doi.org/10.1016/B0-12-369396-9/00431-7.

Kumar, R., Reddy, T., 1991. Digital analysis of lineaments - a test study on South India. Comput. Geosci. 17 (4), 549-559. http://dx.doi.org/10.1016/0098-3004(91)90113-R.

Langridge, R.M., Ries, W.F., Farrier, T., Barth, N.C., Khajavi, N., De Pascale, G.P., 2013. Developing sub 5-m LiDAR DEMs for forested sections of the alpine and hope faults, South Island, New Zealand: implications for structural interpretations. J. Struct. Geol. 64 (2014), 53-66. http://dx.doi.org/10.1016/j.jsg.2013.11.007.

Larue, J.P., 2007. Effects of tectonics and lithology on long profiles of 16 rivers of the southern central massif border between the Aude and the orb (France). Geomorphology 93 (3-4), 343-367. http://dx.doi.org/10.1016/j.geomorph.2007.03.003 (2004)

Lee, Y.J., 1991. Slickenside Petrography: Slip-sense Indicators and Classification (MSc thesis) Department of Geological Sciences, University of New York, Albany, United States (100 p.).

Lee, S., Lee, C.W., 2015. Application of decision-tree model to groundwater productivitypotential mapping. Sustainability 7 (10), 13416-13432. http://dx.doi.org/10.3390/ su71013416.

Leech, D.P., Treloar, P.J., Lucas, N.S., Grocott, J., 2003. Landsat TM analysis of fracture patterns: a case study from the coastal cordillera of northern Chile. Int. J. Remote Sens. 24 (19), 3709-3726. http://dx.doi.org/10.1080/0143116031000102520.

Loisios, D., Tzelepis, N., Nakos, B., 2007. A methodology for creating analytical hill-shading by combining different lighting directions. Proceedings of the 23th International Cartographic Conference, ICC, 4-10 August 2007, Moscow, Russia.

Mark, R.K., 1992. A multidirectional, oblique-weighted, shaded-relief image of the Island of Hawaii. U.S. Geological Survey Open-file Report 92-422 (Version 1.0) Available only at http://pubs.usgs.gov/of/1992/of92-422/ (accessed 05/01/2016).

Maroukian, H., Gaki-Papanastassiou, K., Karymbalis, E., Vouvalidis, K., Pavlopoulos, K. Papanastassiou, D., Albanakis, K., 2008. Morphotectonic control on drainage network evolution in the Perachora Peninsula, Greece. Geomorphology 102 (1), 81-92. http:// dx.doi.org/10.1016/j.geomorph.2007.07.021.

Masoud, A.A., Koike, K., 2011a. Morphotectonics inferred from the analysis of topographic lineaments auto-detected from DEMs: application and validation for the Sinai Peninsula, Egypt. Tectonophysics 510 (3-4), 291-308. http://dx.doi.org/10.1016/j.tecto. 2011.07.010

Masoud, A.A., Koike, K., 2011b. Auto-detection and integration of tectonically significan lineaments from SRTM DEM and remotely-sensed geophysical data. ISPRS J. Photogramm. Remote Sens. 66 (6), 818-832. http://dx.doi.org/10.1016/j.isprsjprs. 2011.08.003.

Miller, J.R., 1991. The influence of bedrock geology on knick point development and channel bed degradation along down-cutting streams in south central Indiana. J. Geol. 99 (4), 591-605.

Mogaji, K.A., Aboyeji, O.S., Omosuyi, G.O., 2011. Mapping of lineaments for groundwate targeting in the basement complex region of Ondo State, Nigeria, using remote sensing and geographic information system (GIS) techniques. Int. J. Water Resour. Environ. Eng. 3 (7), 150-160.

Muhammad, M.M., Awdal, A.H., 2012. Automatic mapping of lineaments using shaded relief images derived from digital elevation model (DEM) in Erbil-Kurdistan, northeast Iraq. Adv. Nat. Appl. Sci. 6 (2), 138-146.

Ollarves, R., Audemard, F., Lopez, M., 2006. Morphotectonic criteria for the identification of active blind thrust faulting in alluvial environments: case studies from Venezuel and Colombia. Z Geomorphol. 145, 81-103.
Onorati, G., Ventura, R., Poscolieri, M., Chiarini, V., Crucillà, U., 1992. The digital elevation model of Italy for geomorphology and structural geology. Catena 19 (2), 147-178. http://dx.doi.org/10.1016/0341-8162(92)90022-4.

Ouchi, S., 1985. Response of alluvial rivers to slow active tectonic movement. Geol. Soc Am. Bull. 96 (4), 504-515. http://dx.doi.org/10.1130/0016-7606(1985)96<504: ROARTS $>2.0 . C O ; 2$

Panizza, M., Castaldini, D., 1987. Neotectonic research in applied geomorphological studies. Z. Geomorphol. 63, 173-211.

Pavlic, G., Singhroy, V., Duk-Rodkin, A., Alasset, P.-J., 2008. Satellite Data Fusion Techniques for Terrain and Surficial Geological Mapping. Vol. 3. IGARSS, pp. 314-317. http://dx.doi.org/10.1109/IGARSS.2008.4779346.

Petit, J.P., 1987. Criteria for the sense of movement on fault surfaces in brittle rocks. J. Struct. Geol. 9 (5-6), 597-608. http://dx.doi.org/10.1016/0191-8141(87)90145-3.

Pike, R.J., 1991. Surface features of central North America: a synoptic view from computer graphics. GSA Today 1 (11), 241-251.

Powell, J.H., 1989a. Stratigraphy and Sedimentation of the Phanerozoic Rocks in Centra and South Jordan, Part A: Ram and Khreim Groups. Geology Directorate, Geological Mapping Division, Bulletin 11, Natural Resources Authority, Amman, Jordan.

Powell, J.H., 1989b. Stratigraphy and Sedimentology of the Phanerozoic Rocks in Centra and South Jordan, Part B: Kurnub, Ajlun and Belqa Group. Geology Directorate, Geological Mapping Division, Bulletin 11, Natural Resources Authority, Amman, Jordan.

Powell, J.H., Moh'd, B.K., 2011. Evolution of Cretaceous to Eocene alluvial and carbonate platform sequences in central and south Jordan. GeoArabia 16 (4), 29-82.

Powell, J.H., Abed, A.M., Le Nindre, Y.M., 2014. Cambrian stratigraphy of Jordan. GeoArabia 19 (3), 81-134

Prasad, A.D., Jain, K., Gairola, A., 2013. Mapping of lineaments and knowledge base preparation using geomatics techniques for part of the Godavari and Tapi basins, India: a case study. Int. J. Comput. Appl. 70 (9), 39-47. http://dx.doi.org/10.5120/11994-7875.

Prasicek, G., Larsen, I.J., Montgomery, D.R., 2015. Tectonic control on the persistence of glacially sculpted topography. Nat. Commun. 6 (8). http://dx.doi.org/10.1038/ ncomms9028.

Qari, M.H.T., Madani, A.A., Matsah, M.I.M., Hamimi, Z., 2008. Utilization of aster and landsat data in geologic mapping of basement rocks of arafat area, Saudi Arabia. Arabian J. Sci. Eng. 33 (1C), 99-116.

Rabb'a, I., 1994. The Geology of the Al Qurayqira (Jabal Hamra Faddan) Map Sheet No. 3051 II, Geology Directorate, Geological Mapping Division, Bulletin 28. Natural Resources Authority, Amman, Jordan.

Radaideh, O.M.A., Melichar, R., 2015. Tectonic paleostress fields in the southwestern part of Jordan: new insights from the fault slip data in the southeastern flank of the Dead Sea fault zone. Tectonics 34 (9), 1863-1891. http://dx.doi.org/10.1002/2015TC003919.

Ramli, M.F., Yusof, N., Yusoff, M.K., Juahir, H., Shafri, H.Z.M., 2010. Lineament mapping and its application in landslide hazard assessment: a review. Bull. Eng. Geol. Environ. 69 (2), 215-233. http://dx.doi.org/10.1007/s10064-009-0255-5.

Rashdan, M., 1988. The Regional Geology of Aqaba-Wadi Araba Area, Sheets 3049-III, 2949-II, Geology Directorate, Geological Mapping Division, Bulletin 7. Natural Resources Authority, Amman, Jordan.

Ray, R.G., 1960. Aerial Photographs in Geologic Interpretation and Mapping. U.S. Geologcal Survey Professional Paper 373, Washington, USA (230 p).

Ribolini, A., Spagnolo, M., 2007. Drainage network geometry versus tectonics in the Argentera massif (French-Italian Alps). Geomorphology 93 (3-4), 253-266. http:// dx.doi.org/10.1016/j.geomorph.2007.02.016 (2008).

Ricchetti, E., Palombella, M., 2007. Production of geological lineament map of southern Italy using landsat 7 ETM + imagery. Ital. J. Geosci. 126 (3), 567-572.

Robl, J., Hergarten, S., Stüwe, K., 2008. Morphological analysis of the drainage system in the eastern alps. Tectonophysics 460 (1-4), 263-277. http://dx.doi.org/10.1016/j. ecto.2008.08.024.

Saadi, N.M., Abdel Zaher, M., El-Baz, F., Watanabe, K., 2011. Integrated remote sensing data utilization for investigating structural and tectonic history of the Ghadames Basin, Libya. Int. J. Appl. Earth Obs. Geoinf. 13 (5), 778-791. http://dx.doi.org/10. 1016/j.jag.2011.05.016.

Sarp, G., 2005. Lineament Analysis from Satellite Images, North-west of Ankara (M.Sc Dissertation) School of Natural and Applied Science, Middle East Technical University, Ankara (76 p.).

Schetselaar, E.M., 2001. On preserving spectral balance in image fusion and its advantages for geological image interpretation. Photogramm. Eng. Remote. Sens. 67 (8), 925-934.

Schumm, S.A., 1986. Alluvial river response to active tectonics. In: Geophysics Study Committee (Ed.), Active Tectonics, Studies in Geophysics Series. National Academy Press, Washington, pp. 80-94.

Schumm, S.A., Dumont, J.F., Holbrook, J.M., 2002. Active Tectonics and Alluvial Rivers. Cambridge University Press, New York.

Seeber, L., Gornitz, V., 1983. River profiles along the Himalayan arc as indicators of active tectonics. Tectonophysics 92 (4), 335-367. http://dx.doi.org/10.1016/00401951(83)90201-9.

Shahzad, F., Mahmood, S.A., Gloaguen, R., 2009. Drainage network and lineament analysis: an approach for Potwar Plateau (northern Pakistan). J. Mt. Sci. 6 (1), 14-24. http://dx.doi.org/10.1007/s11629-009-0206-4.

Shake, S.N., McHone, J.G., 1987. Topographic lineaments and their geologic significance in Central New England and adjacent New York. Northeast. Geol. 9 (3), 120-128.

Shamsi, U.M., 2008. Arc hydro: a framework for integrating GIS and hydrology. J. Water Manage. Model. R228-11, 165-181. http://dx.doi.org/10.14796/JWMM.R228-11.

Sharma, A., Tiwari, K.N., Bhadoria, P.B.S., 2011. Determining the optimum cell size of digital elevation model for hydrologic application. J. Earth Syst. Sci. 120 (4), 573-582. http://dx.doi.org/10.1007/s12040-011-0092-3.

Simpson, D.W., Anders, M.H., 1992. Tectonics and topography of the western United States an application of digital mapping. GSA Today 2 (6) (pp. 117, 118, 120, 121). 
Štěpančíková., P., Stemberk, J., Vilímek, V., Košt'ák, B., 2008. Neotectonic development of drainage networks in the east Sudeten Mountains and monitoring of recent fault displacements (Czech Republic). Geomorphology 102 (1), 68-80. http://dx.doi.org/10. 1016/j.geomorph.2007.06.016.

Stern, R.J., 1994. Arc-assembly and continental collision in the Neoproterozoic east African Orogen: implications for the consolidation of Gondwanaland. Annu. Rev. Earth Planet. Sci. 22, 319-351. http://dx.doi.org/10.1146/annurev.ea.22.050194.001535.

Stern, R.J., Ali, K.A., Liégeois, J.P., Johnson, P.R., Kozdroj, W., Kattan, F.H., 2010. Distribution and significance of pre-Neoproterozoic zircons in juvenile Neoproterozoic igneous rocks of the Arabian-Nubian shield. Am. J. Sci. 310 (9), 791-811. http://dx.doi.org/ 10.2475/09.2010.02

Stockli, R., Vermote, E., Saleous, N., Simmon, R., Herring, D., 2005. The Blue Marble Next Generation-A True Color Earth Dataset Including Seasonal Dynamics From MODIS. Dataset User's manual, NASA Earth Observatory.

Stoeser, D.B., Frost, C.D., 2005. Nd, Pb, Sr, and O isotopic characterization of Saudi Arabian shield terranes. Chem. Geol. 226 (3-4), 163-188. http://dx.doi.org/10.1016/j. chemgeo.2005.09.019 (2006).

Suzen, M.L., Toprak, V., 1998. Filtering of satellite images in geological lineament analyses: an application to a fault zone in Central Turkey. Int. J. Remote Sens. 19 (6), 1101-1114. http://dx.doi.org/10.1080/014311698215621.

Taymaz, T., Jackson, J., McKenzie, D., 1991. Active tectonics of the north and central Aegean Sea. Geophys. J. Int. 106 (2), 433-490. http://dx.doi.org/10.1111/j.1365-246X. 1991.tb03906.x.

Tchoukanski, I., 2015. EasyCalculate 10, a Set of Expressions for ArcGIS 10. ET Spatial Techniques, Pretoria, South Africa. Available online at http://www.ian-ko.com (accessed 06/01/2016).

Terrizzano, C.M., Cortés, J.M., Zech, R., Morabito, E.G., 2014. Drainage anomalies as indicators of soft-linked deformation zones between neotectonic structural highs in the Precordillera, Central Andes of Argentina. Geomorphology 224, 1-15. http://dx.doi. org/10.1016/j.geomorph.2014.07.004.

Turcotte, R., Fortin, J.-P., Rousseau, A.N., Massicotte, S., Villeneuve, J.-P., 2000. Determination of the drainage structure of a watershed using a digital elevation model and a digital river and lake network. J. Hydrol. 240 (3-4), 225-242. http://dx.doi.org/10. 1016/S0022-1694(00)00342-5 (2001).

Twidale, C.R., 2004. River patterns and their meaning. Earth Sci. Rev. 67 (3-4), 159-218. http://dx.doi.org/10.1016/j.earscirev.2004.03.001.
Vail, J.R., 1983. Pan-African crustal accretion in Northeast Africa. J. Afr. Earth Sci. 1 (3-4), 285-294. http://dx.doi.org/10.1016/S0731-7247(83)80013-5.

Valdiya, K.S., Rajagopalan, G., 2000. Large palaeolakes in Kaveri basin in Mysore Plateau: late quaternary fault reactivation. Curr. Sci. 78 (9), 1138-1142.

Vannoli, P., Basili, R., Valensise, G., 2004. New geomorphic evidence for anticlinal growth driven by blind-thrust faulting along the northern Marche coastal belt (central Italy). J. Seismol. 8 (3), 297-312. http://dx.doi.org/10.1023/B:JOSE.0000038456.00574.e3.

Walker, J.D., Geissman, J.W., Bowring, S.A., Babcock, L.E., 2012. Geologic Time Scale v. 4.0. Geological Society of America, Colorado http://dx.doi.org/10.1130/2012.CTS004R3C.

Westaway, R., 1994. Present-day kinematics of the Middle East and eastern Mediterranean. J. Geophys. Res. 99 (B6), 12071-12090. http://dx.doi.org/10.1029/94JB00335.

Woodcock, N.H., Schubert, C., 1994. Continental strike-slip tectonics. In: Hancock, P.L (Ed.), Continental Deformation. Pergamon Press, Oxford, pp. 251-263.

Zain-Eldeen, U., Delvaux, D., Jacobs, P., 2002. Tectonic Evolution in the Wadi Araba Segment of the Dead Sea Rift, South-West Jordan. European Geosciences Union, Special Publication Series Vol. 2 pp. 63-81.

Zaprowski, B.J., Evenson, E.B., Pazzaglia, F.J., Epstein, J.B., 2001. Knickzone propagation in the Black Hills and northern High Plains: a different perspective on the late Cenozoic exhumation of the Laramide Rocky Mountains. Geol. Soc. Am. 29 (6), 547-550. http://dx.doi.org/10.1130/0091-7613(2001)029<0547:KPITBH>2.0.CO;2 (Wyoming, USA).

Zárate, M.A., Mehl, A., Perucca, L., 2014. Quaternary evolution of the cordillera frontal piedmont between c. $33^{\circ}$ and $34^{\circ} \mathrm{S}$ Mendoza, Argentina. In: Sepulveda, S.A. Giambiagi, L.B., Moreiras, S.M., Pinto, L., Tunik, M., Hoke, G.D., Farias, M. (Eds.), Geodynamic Processes in the Andes of Central Chile and Argentina. Geological Society, London, pp. 293-310 (Special Publications 399).

Zernitz, E.R., 1932. Drainage patterns and their significance. J. Geol. 40 (6), 498-521. http://dx.doi.org/10.1086/623976.

Zhang, Y., 2008. Pan-sharpening for improved information extraction. In: Li, Z., Chen, J. Baltsavias, E. (Eds.), Advances in Photogrammetry, Remote Sensing and Spatial Information Sciences. Taylor \& Francis Group, London, pp. 185-203.

Zhang, W., Montgomery, D.R., 1994. Digital elevation model grid size, landscape representation, and hydrologic simulations. Water Resour. Res. 30 (4), 1019-1028. http://dx. doi.org/10.1029/93WR03553. 